\title{
Benign mimickers of prostatic adenocarcinoma
}

\author{
John R Srigley \\ Department of Pathology and Molecular Medicine, McMaster University, Hamilton, ON, Canada
}

\begin{abstract}
The diagnosis of prostatic adenocarcinoma, especially when present in small amounts, is often challenging. Before making a diagnosis of carcinoma, it is prudent for the pathologist to consider the various benign patterns and processes that can simulate prostatic adenocarcinoma. A useful method of classifying benign mimickers is in relationship to the major growth patterns depicted in the classical Gleason diagram. The four major patterns are small gland, large gland, fused gland and solid. Most mimickers fit within the small gland category and the most common ones giving rise to false-positive cancer diagnosis are atrophy, post-atrophic hyperplasia, atypical adenomatous hyperplasia and seminal vesicle-type tissue. A number of other histoanatomic structures such as Cowper's gland, verumontanum mucosal glands, mesonephric glands and paraganglionic tissue may be confused with adenocarcinoma. Additionally, metaplastic and hyperplastic processes within the prostate may be confused with adenocarcinoma. Furthermore, inflammatory processes including granulomatous prostatitis, xanthogranulomatous prostatitis and malakoplakia may simulate highgrade adenocarcinoma. Atypical adenomatous hyperplasia (adenosis), a putative precursor of transition zone adenocarcinoma, has overlapping features with low-grade adenocarcinoma and may cause problems in differential diagnosis, especially in the needle biopsy setting. The pathologist's awareness of the vast array of benign mimickers is important in the systematic approach to the diagnosis of prostatic adenocarcinoma. Knowledge of these patterns on routine microscopy coupled with the prudent use of immunohistochemistry will lead to a correct diagnosis and avert a false-positive cancer interpretation.
\end{abstract}

Modern Pathology (2004) 17, 328-348, advance online publication, 13 February 2004; doi:10.1038/modpathol.3800055

Keywords: prostate gland; adenocarcinoma; mimickers; benign

Prostatic adenocarcinoma is characterized by diverse architectural patterns and as such can be confused with other histological patterns and processes. Histoanatomic structures such as seminal vesicle, inflammatory and reactive conditions and pathophysiological processes including atrophy, hyperplasia and metaplasia have protean patterns which may simulate adenocarcinoma. Most of these lesions are readily recognized and easily separated from malignancy but they may present problems, especially when dealing with limited sampling in thin core needle biopsies. False-positive cancer diagnosis, albeit uncommon, may be rendered in some cases leading to serious clinical, psychological and medicolegal consequences. Prostatic biopsy pathology has been identified as a problem area which may lead to litigation. ${ }^{1-3}$ In my own experience, the most likely patterns giving rise to false-

Correspondence: JR Srigley, Department of Laboratory Medicine, The Credit Valley Hospital, 2200 Eglinton Avenue West, Mississauga, ON, Canada L5M 2N1.

E-mail: jsrigley@cvh.on.ca

Received 30 June 2003; accepted 30 June 2003; published online 13 February 2004 positive malignant cells are atrophy, post-atrophic hyperplasia, atypical adenomatous hyperplasia (adenosis) and seminal vesicle.

In this paper, the differential diagnosis of prostatic adenocarcinoma will be discussed with emphasis on benign mimickers as outlined in Table 1 . Prostatic intraepithelial neoplasia and other carcinomas may be confused with prostatic adenocarcinoma but these topics will not be addressed. The mimickers of other rare prostatic malignancies such as sarcoma will not be covered. The differential diagnosis of adenocarcinoma has been detailed in several recent reviews and monographs. ${ }^{4-10}$

\section{A pattern-based approach to differential diagnosis}

The utility of the now famous Gleason diagram extends beyond its role as a grading tool. ${ }^{11,12}$ It is useful in a discussion of the protean architectural patterns that are important in diagnosing prostatic adenocarcinoma. Additionally, it provides a conceptual framework for discussing differential diagnosis. In the Gleason diagram, there are nine 
Table 1 Classification of benign mimickers of adenocarcinoma

\begin{tabular}{lc}
\hline Histoanatomic structures & Reactive atypia \\
Seminal vesicle/ejaculatory & Inflammatory \\
duct & Ischemic \\
Cowper's gland & Radiation \\
Paraganglion & \\
Verumontanum mucosal & Metaplasia \\
glands (hyperplasia) & Mucinous \\
Mesonephric gland & Nephrogenic (adenoma) \\
remnants (hyperplasia) & \\
Atrophy & Prostatic hyperplasia \\
Simple (lobular) & Basal cell hyperplasia \\
Sclerotic & Benign nodular hyperplasia, \\
Cystic & small gland pattern \\
Linear (streaming) & (Clear cell) cribriform \\
Post-atrophic hyperplasia & hyperplasia \\
(partial atrophy) & Sclerosing adenosis \\
Inflammation & Atypical adenomatous \\
Usual prostatitis with & hyperplasia (adenosis) \\
preservation artifacts & \\
Granulomatous prostatitis, & \\
nonspecific & \\
Xanthogranulomatous & \\
prostatitis (xanthoma) & \\
Malakoplakia & \\
\hline
\end{tabular}

patterns which can be lumped into four major architectural categories for discussion of differential diagnosis (see Figure 1 and Table 2).

The predominant pattern of adenocarcinoma is the small glandular one. This corresponds to Gleason patterns 1, 2, 3A, 3B and consists of separate acini which may be tiny, small or medium in size. Most benign mimickers enter the differential diagnosis of small acinar adenocarcinoma.

The second major pattern is the large glandular one. Medium to large simple acini and/or papillary and cribriform structures are seen. Central (comedo) necrosis involving round duct-like structures may also be identified. The large gland architecture includes Gleason patterns 3A, 3C and 5A.

The third major growth pattern of adenocarcinoma is fused glandular which comprises Gleason patterns 4A and 4B. The infiltrating coalesced glands may be either amphophilic (Gleason 4A) or clear (so-called hypernephroid; Gleason 4B). A few structures and benign processes simulate this fused gland pattern.

The final major pattern of adenocarcinoma is the solid one which consists of sheets, cords and single infiltrating cells and corresponds to a pattern 5B in the Gleason chart. Certain inflammatory lesions may be confused with solid adenocarcinoma.

A benign mimicker may in some situations simulate more than one major pattern of adenocarcinoma. For instance, reactive atypia involving small acini can be mistaken for small acinar carcinoma. However, if the atypia affects medium to large glands, then the differential diagnosis is with the large gland pattern of carcinoma.

\section{PROSTATIC ADENOCARCINOMA} (Histologic Grades)

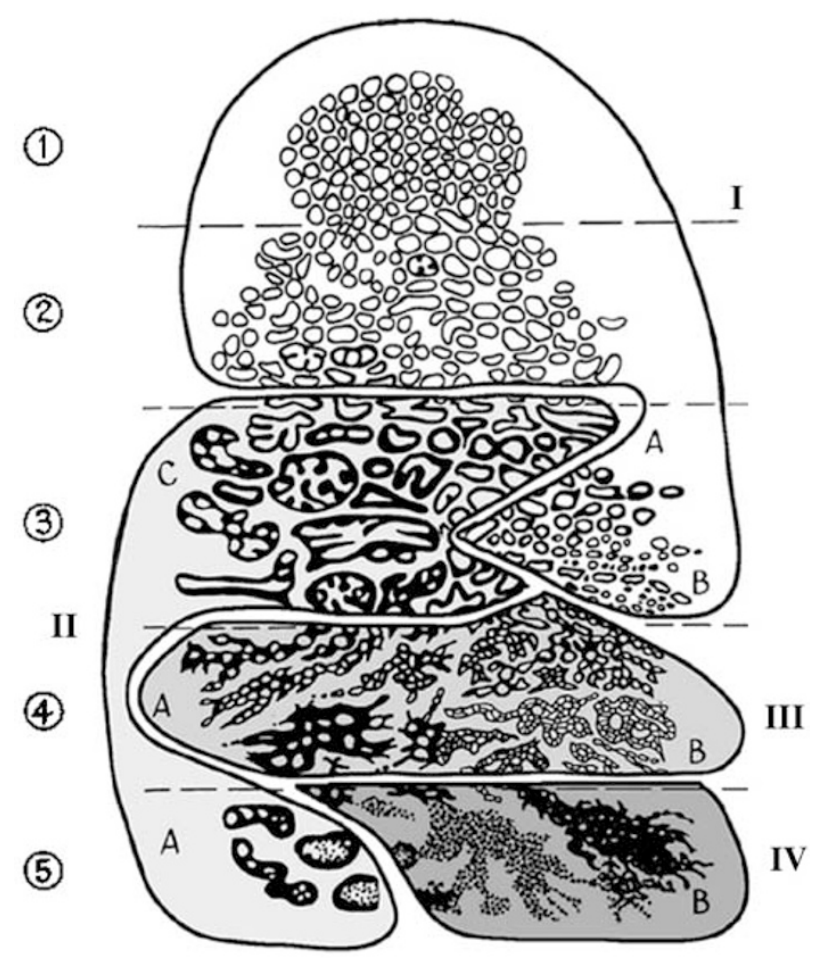

Figure 1 Gleason diagram divided into four major architectural patterns of prostatic adenocarcinoma. I—small gland pattern; IIlarge gland pattern; III-fused gland pattern; IV—solid pattern (see Table 2).

Table 2 Major growth patterns of adenocarcinoma

\begin{tabular}{|c|c|c|c|}
\hline & $\begin{array}{l}\text { Growth } \\
\text { pattern }\end{array}$ & $\begin{array}{l}\text { Gleason } \\
\text { patterns }\end{array}$ & Descriptors \\
\hline I & Small gland & $1,2,3 \mathrm{~A}, 3 \mathrm{~B}$ & $\begin{array}{l}\text { Tiny, small, medium, } \\
\text { separate acini }\end{array}$ \\
\hline II & Large gland & $3 \mathrm{~A}, 3 \mathrm{C}, 5 \mathrm{~A}$ & $\begin{array}{l}\text { Simple, papillary, cribriform, } \\
\text { comedo }\end{array}$ \\
\hline III & Fused gland & $4 \mathrm{~A}, 4 \mathrm{~B}$ & $\begin{array}{l}\text { Coalescing acini, } \\
\text { amphophilic or clear } \\
\text { (hypernephroid) }\end{array}$ \\
\hline IV & Solid & $5 B$ & Sheets, cords, single cells \\
\hline
\end{tabular}

The benign mimickers and the corresponding patterns of adenocarcinoma that may be simulated are shown in Table 3. The discussion of these entities will follow this pattern-based approach.

\section{Small Gland Pattern}

Seminal vesicle

Seminal vesicle tissue may be present in transurethral resectates or in needle biopsies, usually unexpectedly, but sometimes as a result of specific sampling. ${ }^{13,14}$ The seminal vesicle is characterized by a central lumen with branching glands surrounded by smooth muscle. Commonly, the end 
Table 3 Benign mimickers in relation to major growth patterns of prostatic adenocarcinoma

\begin{tabular}{lc}
\hline Small gland pattern & Large gland pattern \\
Seminal vesicle & (Clear cell) cribriform \\
Cowper's gland & hyperplasia \\
Atrophy & Adenoid cystic-like basal \\
Post-atrophic hyperplasia & cell hyperplasia \\
Reactive atypia & Reactive atypia \\
Mucinous metaplasia & \\
Nephrogenic metaplasia & Fused gland pattern \\
(adenoma) & Paraganglioma \\
Basal cell hyperplasia & Xanthogranulomatous \\
Benign nodular hyperplasia & inflammation (xanthoma) \\
Sclerosing adenosis & Malakoplakia \\
Verumontanum & \\
Mucosal gland & Solid pattern \\
hyperplasia & Usual prostatitis with crush \\
Mesonephric gland & artifacts \\
hyperplasia & Idiopathic granulomatous \\
Atypical adenomatous & prostatitis \\
hyperplasia & Signet ring-like change in \\
& lymphocytes and stromal \\
& cells
\end{tabular}

branching is complex with numerous small glands, resulting in the so-called adenotic pattern of seminal vesicle (Figure 2). This latter pattern can present problems, especially when the overall gland structure and central lumen are not recognized. Tangential sampling of adenotic areas in a needle biopsy may produce a small gland pattern causing confusion with small acinar carcinoma. ${ }^{15}$ Helpful features to distinguish adenotic seminal vesicle include the presence of nuclear hyperchromasia and pleomorphism which at times is striking. ${ }^{13,16}$ The degree of atypia is thought to increase with advancing age. ${ }^{13}$ Atypical cells are found centrally within the acini and they are often more atypical than the nuclei of small acinar carcinoma (Figure 2). Mitoses are not identified. Small nuclear pseudoinclusions are commonly seen. In the cytoplasm, golden-brown lipofuscin pigment is usually identified, although the amount varies from case to case. When prominent, the diagnosis of seminal vesicle epithelium is easily supported.

It must be remembered however that lipofuscin pigment may be present in normal, hyperplastic, preneoplastic (PIN) and carcinomatous glands. ${ }^{17-19}$ The presence of lipofuscin pigment in small acinar carcinoma however is rare. When the epithelial atypia and pigmentation are not prominent, a significant diagnostic challenge may result. In problematic cases, negative immunohistochemistry for prostatic-specific antigen (PSA) and prostatic acid phosphatase (PAP) helpful. Additionally, the $34 \beta$ E12 stain shows basal cells in seminal vesicular glands which of course are absent in small acinar carcinoma.

Ejaculatory duct epithelium has a similar morphology to that of the seminal vesicle. Ejaculatory ducts however are surrounded by a band of loose
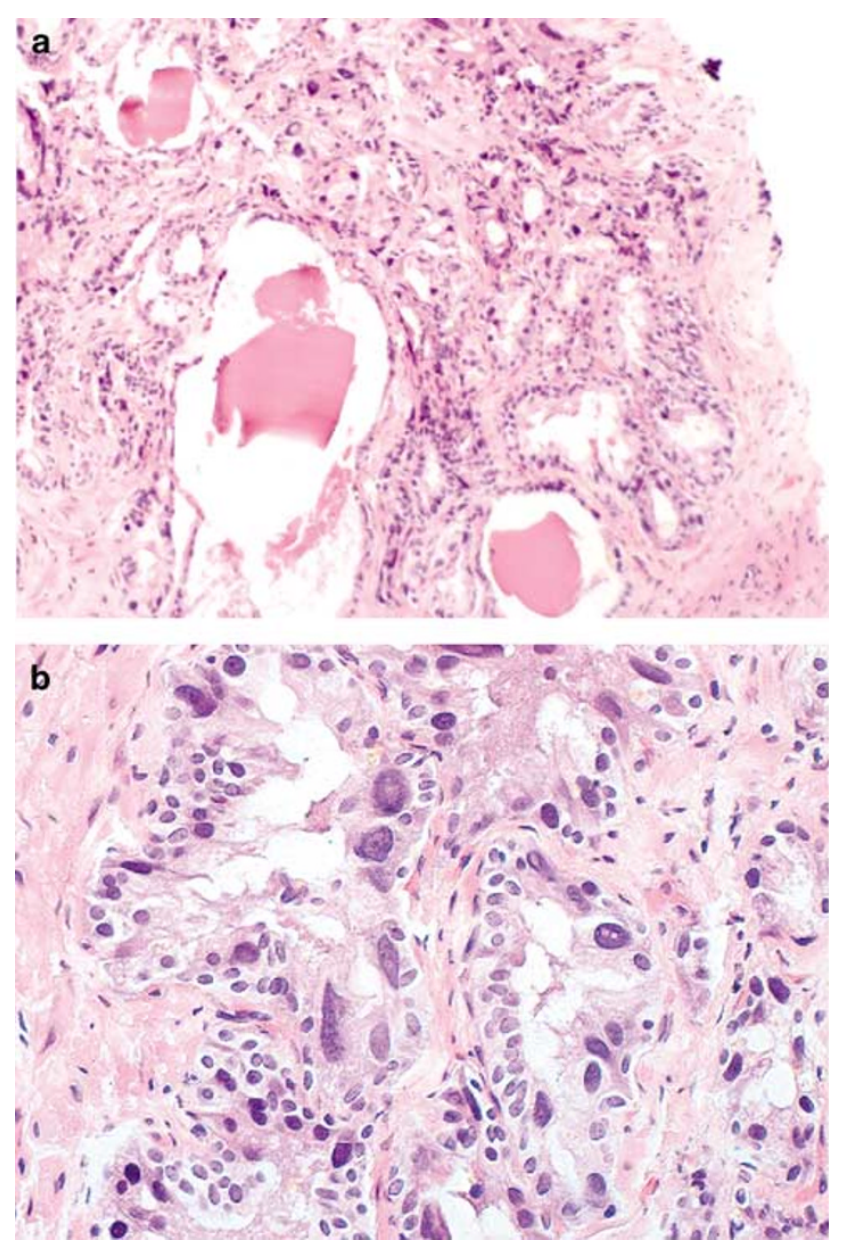

Figure 2 (a) Low-power photomicrograph showing seminal vesicle with dilated central glands and peripheral small 'adenotic' glands. (b) High-power photomicrograph of seminal vesicle glands showing nuclear atypia within luminal cells and focal cytoplasmic lipofuscin pigment.

fibrovascular connective tissue and lack the wellformed muscular wall of seminal vesicle. This distinction is of practical importance since the presence of carcinoma in ejaculatory duct tissue does not indicate extraprostatic disease whereas carcinomatous involvement of seminal vesicle proper indicates high stage disease (at least stage pT3b) and has adverse prognostic significance.

\section{Cowper's gland}

Cowper's glands, also referred to as the bulbourethral glands are paired periurethral structures located near the prostatic apex.. ${ }^{20,21}$ They are rarely sampled in prostatic specimens. Cowper's glands have a lobular configuration with a central duct surrounded by tightly packed round acini composed of cells with abundant mucinous cytoplasm (Figure $3)$. The nuclei are basally located and uniform. Sometimes, skeletal muscle, typical of the apical region, is present in the periglandular stroma. Cowper's glands are rarely confused with small 


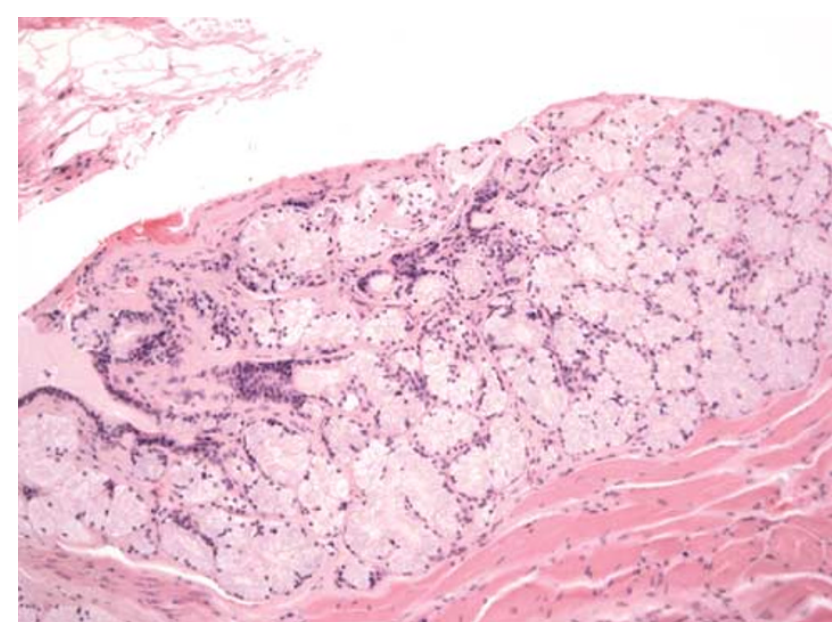

Figure 3 Cowper's gland. Note uniform collection of mucinous acini with excretory duct (left).

acinar carcinoma. The duct-acinar architecture, cytoplasmic mucin and lack of cellular atypia distinguish Cowper's glands from adenocarcinoma. In difficult cases, special stains for mucin (mucicarmine, PAS-D) may be employed. Cowper's glands show variable staining results for PSA and are negative for PAP. ${ }^{20,21}$ The ductal cells exhibit high molecular weight keratin (34ßE12) staining and in some cases attenuated cells around the periphery of the acini are also positive. ${ }^{20}$ The latter cells may also exhibit smooth muscle actin positivity. ${ }^{20,21}$ Another differential diagnosis of Cowper's glands is mucinous metaplasia of prostatic acini which is usually seen in association with atrophy. ${ }^{22}$

\section{Atrophy}

Atrophy of prostatic glands is a common process typically but not exclusively found in older patients. Atrophy may be seen in the young adult prostate and is commonly admixed with areas of nodular prostatic hyperplasia. ${ }^{23}$ While common in the peripheral zone, atrophy may also be seen in the central and transition zones. Glandular atrophy is commonly associated with chronic prostatitis which may have an active component characterized by intraglandular neutrophils. Some recent evidence suggests that prostatic atrophy may be a manifestation of chronic ischemic disease, although many examples of atrophy are still considered idiopathic in nature. ${ }^{24}$ Atrophy can also be the result of treatment with radiation and antiandrogens ${ }^{25-30}$ (Figure 4). Treatment-associated atrophy is frequently extensive and severe and in the case of radiation may be associated with epithelial atypia.

Four main patterns of atrophy are recognizedlobular (simple), sclerotic, cystic and linear or streaming (Figure 5). Combined patterns are common. Lobular (simple) atrophy is characterized by small glands arranged in circumscribed (lobular) nests. The orderly architecture is best appreciated

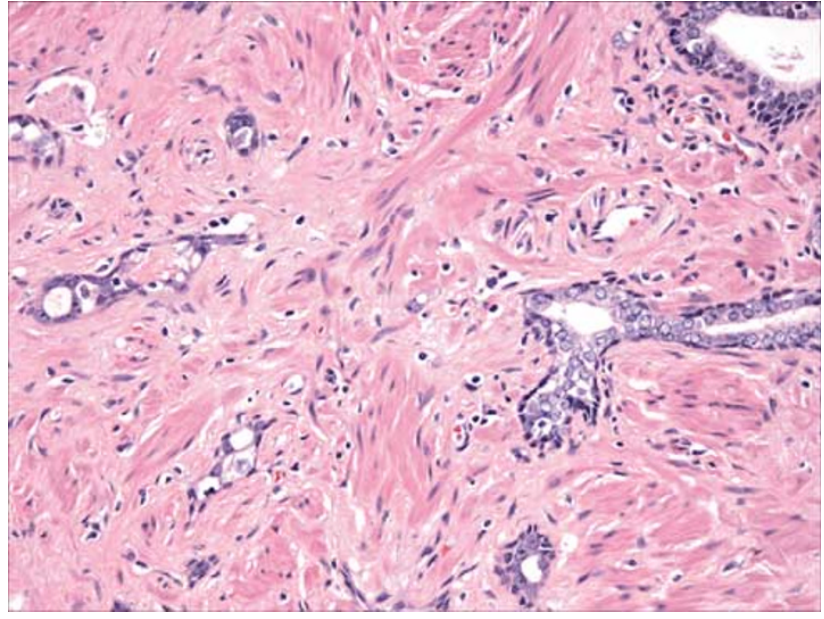

Figure 4 Atrophy in association with antiandrogen effects-note prominent basal cell layer and tiny irregular acini with pseudoinfiltrative growth pattern.

on low power. In sclerotic atrophy, the small glands are distorted by dense collagenized stroma which results in sharply angulated and irregular shapes. The stroma often has an elastotic appearance similar to that seen in some breast conditions. At low power, the lobular architecture is usually evident and sometimes a central dilated duct is appreciated. The almost desmoplastic appearance of the stroma in sclerotic atrophy contrasts with low grade, small acinar carcinoma which incites little or no stromal response. In cystic atrophy, varying degrees of acinar dilatation are seen and usually other areas of more typical simple atrophy are found nearby. Occasionally, atrophy may have a linear, streaming pattern in which small dark acini are lined up in a row, seemingly permeating through stroma. This latter pattern is particularly prone to be overinterpreted as carcinoma.

Regardless of the architectural subtype of atrophy, the cytological features are similar. The cells are small, shrunken and dark. They have high nuclear to cytoplasmic ratios but the nuclei are uniform and lack nuclear membrane irregularity and chromatin abnormalities. Occasionally, small chromocenters are seen but prominent nucleoli are absent. Double layering of cells is often seen but in some instances it may be difficult to appreciate because of the marked secretory cell atrophy (Figure 6). In such cases, stains for high molecular weight keratin (34 $\beta$ E12) may be employed to highlight the basal cell compartment. ${ }^{31}$

The important features in separating atrophy from small acinar carcinoma are the low power maintenance of lobular architecture at least in part, uniform cytology and absence of prominent nucleoli. In some cases, especially when the atrophy is along the edge of a biopsy or when distortion or secondary inflammation is present, diagnosis may be difficult and special stains for high molecular weight keratin should be employed. 

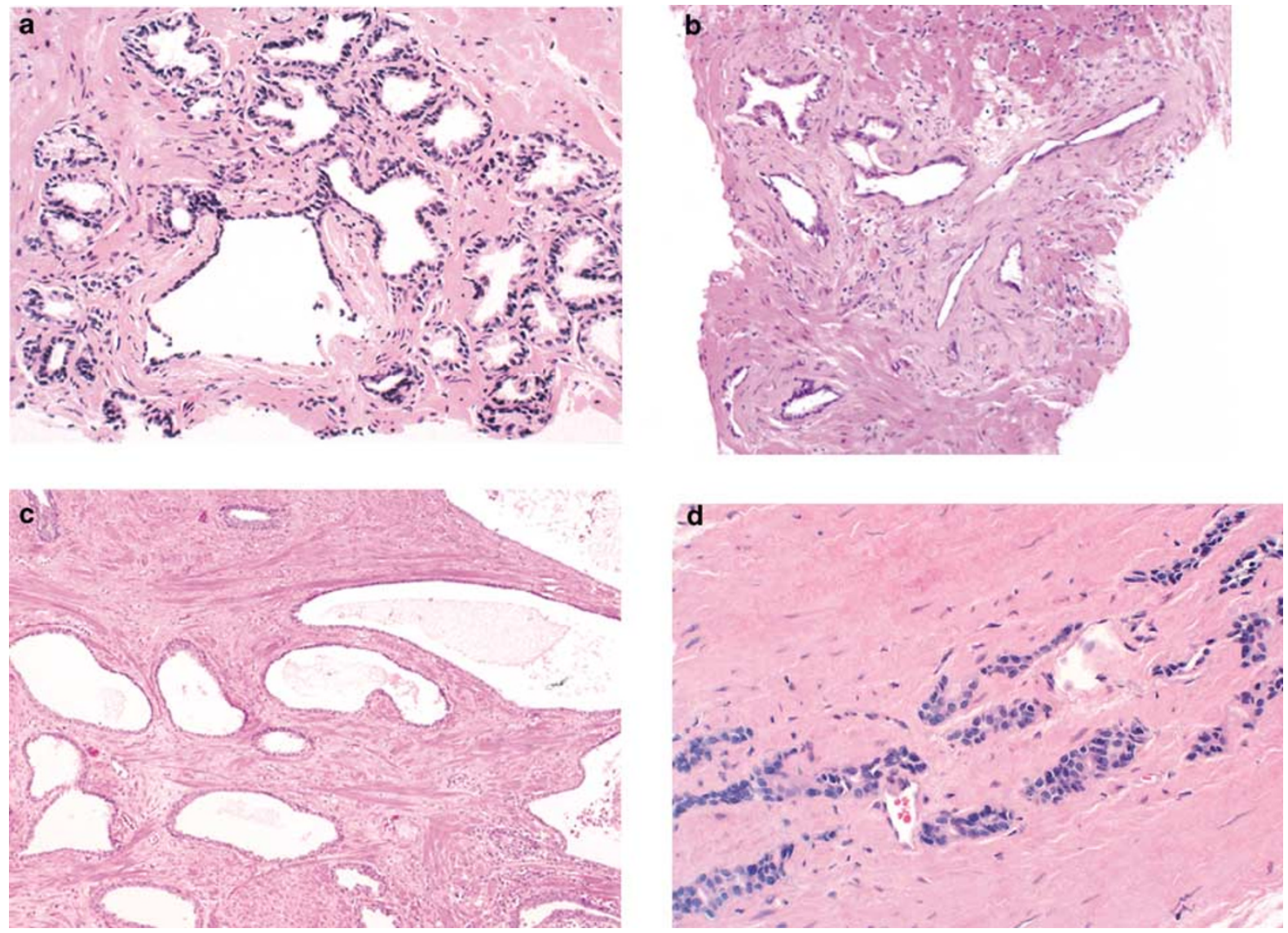

Figure 5 Patterns of atrophy. (a) Simple lobular; (b) Sclerotic; (c) Cystic; (d) Linear or streaming.

In a series of secondary reviews of prostatic pathology prior to definitive treatment, atrophy was a lesion in needle biopsies sometimes overinterpreted as adenocarcinoma. ${ }^{32}$ It should be emphasized that carcinoma may have an atrophic appearance and as such may be underinterpreted as atrophy. Atrophic adenocarcinomas are composed of small dark acini usually with an irregular permeative pattern of growth. On close inspection, there is nuclear atypia and nucleoli are usually recognized at least focally. In some instances, 34 $\beta \mathrm{E} 12$ staining may be required to distinguish the atrophic adenocarcinoma from atrophy. $^{33,34}$

Atrophy associated with inflammation, especially active inflammation, may be particularly challenging and one should be cautious in diagnosing carcinoma in inflamed small gland foci. Additionally, in the setting of radiation, atrophy may be severe and may be associated with stromal fibrosis. This may result in architectural distortion which when coupled with cytological atypia typical of radiation effects can cause considerable diagnostic confusion. In such cases, high molecular weight keratin stains $(34 \beta E 12)$ are useful to separate non-neoplastic atrophic glands from residual carcinoma.
Post-atrophic hyperplasia

Post-atrophic hyperplasia, also referred to as partial atrophy or hyperplastic atrophy is an uncommon histological process found in about $2-3 \%$ of prostatic needle biopsy cases. ${ }^{35-38}$ It is usually found in the peripheral zone. In most cases, it is difficult to know if post-atrophic hyperplasia represents a normal or hyperplastic focus undergoing atrophy (partial atrophy) or secondary hyperplasia occurring in atrophic areas. Studies with proliferation markers however show increased proliferation in areas of post-atrophic hyperplasia, thus supporting the latter hypothesis. ${ }^{39,40}$

Post-atrophic hyperplasia consists of a combination of atrophic acini and ones that contain more abundant clear or amphophilic cytoplasm and appear hyperplastic (Figure 7). The lobular arrangement is usually maintained and there is often apparent budding of 'neoacini' lined by cuboidal cells with clear cytoplasm. A mixture of cells with atrophic and nonatrophic cytoplasm leads to a variety of irregular glandular shapes including stellate ones. Some nuclear enlargement may be seen and rarely, enlarged nucleoli are identified. The busy architecture of post-atrophic hyperplasia may cause diagnostic confusion with adenocarcinoma, however there is generally a maintenance of some 

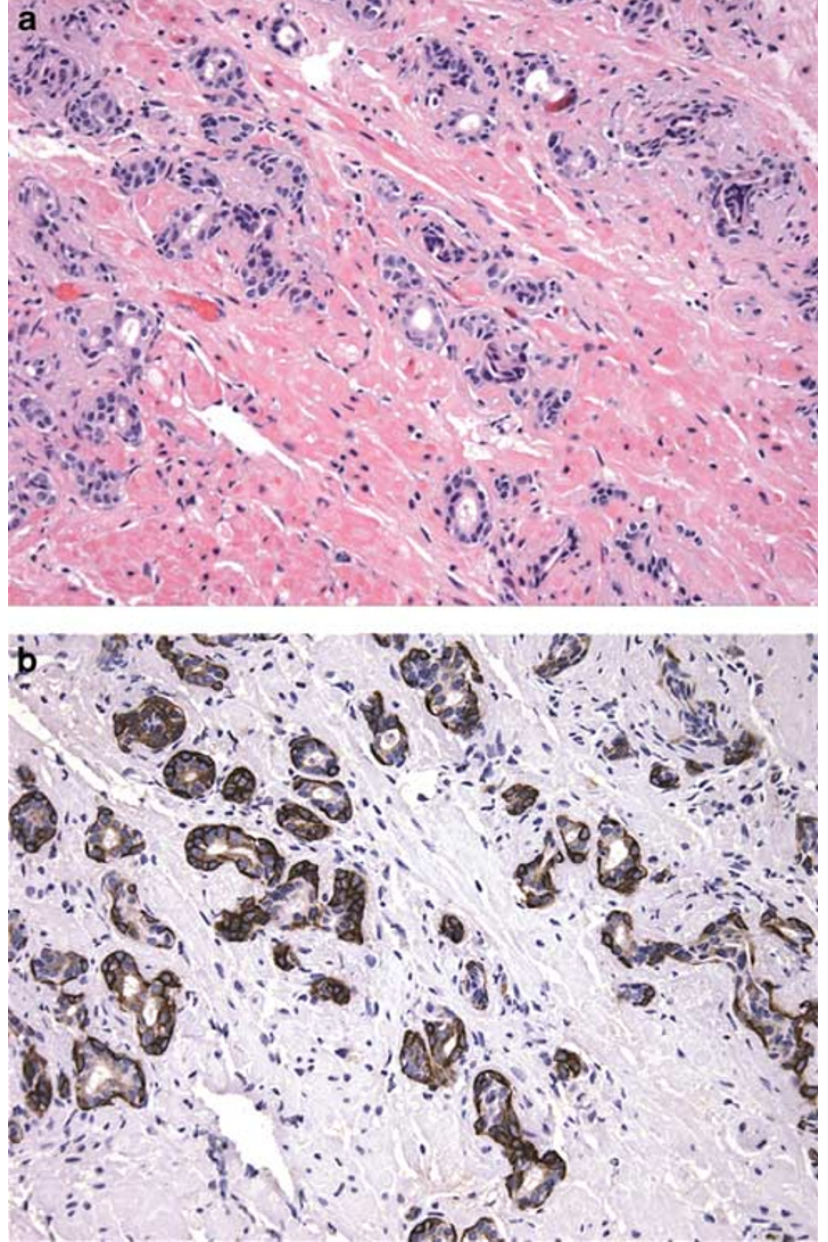

Figure 6 (a) Atrophy with pseudoinfiltrative growth pattern. (b) High molecular weight keratin stain showing prominent basal cell staining.

degree of lobular architecture and basal cells are usually recognized, even at the H\&E level. Caution should be exercised whenever there is an admixture of atrophic and nonatrophic acini, especially when a lobular pattern is not readily recognized. Prominent nucleoli in a significant number of cells are not typically found in post-atrophic hyperplasia. The prudent use of high molecular weight keratin (34ßE12) immunostains is important in difficult cases. There is a discontinuous layer of basal cells in post-atrophic hyperplasia whereas in small acinar carcinoma, the basal cell layer is completely absent. In rare instances, luminal crystalloids and even small amounts of basophilic luminal mucus may be present in post-atrophic hyperplasia.

The early ideas of Franks and Laivag that atrophy and post-atrophic hyperplasia are involved in the pathogenesis of prostatic cancer were largely ignored until recently. ${ }^{35,39}$ The common topographic association of prostatic carcinoma, atrophy and chronic inflammation is well known but most investigations had been focused on other putative precursors such as prostatic intraepithelial neoplasia (PIN) and atypical adenomatous hyperplasia
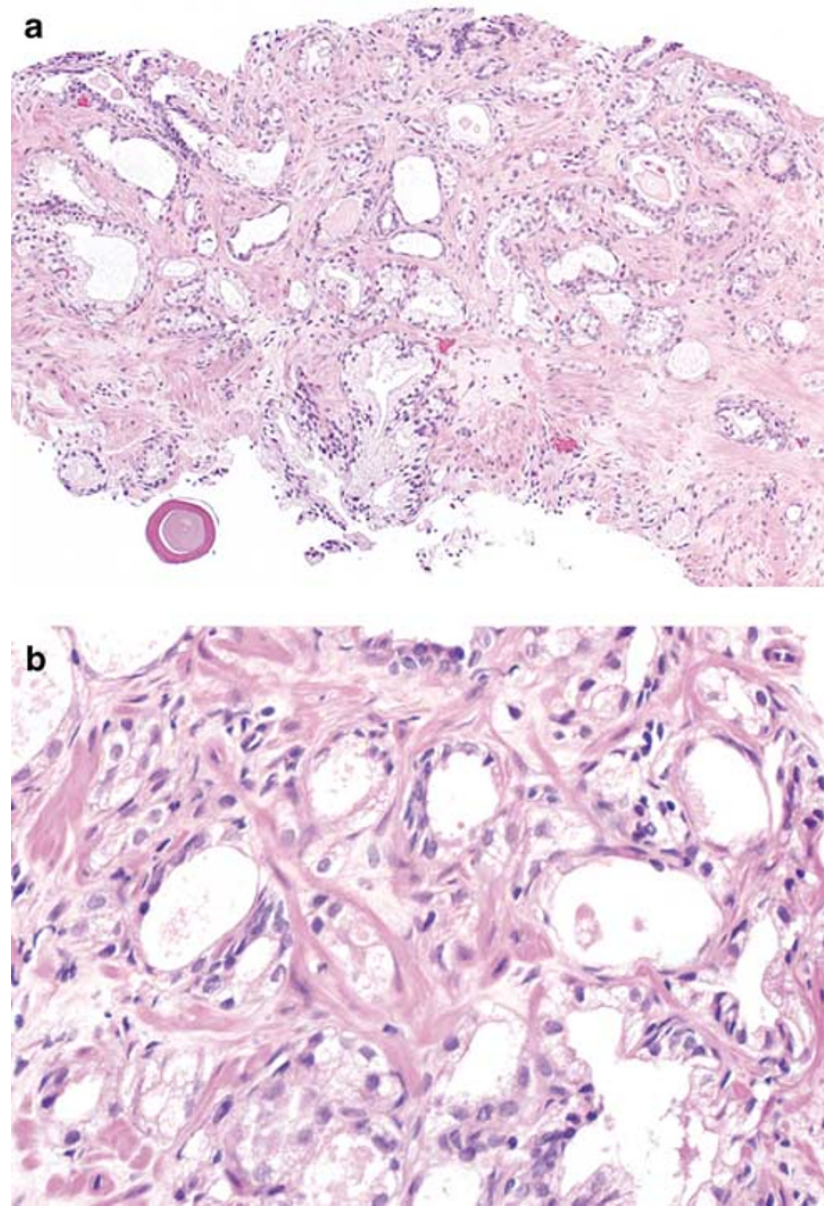

Figure 7 Post-atrophic hyperplasia. (a) Low-power photomicrograph showing mixture of shrunken atrophic glands and ones with more abundant clear cytoplasm. At the periphery there are some tiny apparent neoacini. (b) High-power photomicrograph showing admixture of small atrophic and hyperplastic glandsnote absence of significant nuclear atypia.

(adenosis). De Marzo and co-workers have recently identified a lesion which they refer to as proliferative inflammatory atrophy which may represent a precursor of adenocarcinoma. ${ }^{40-42}$ This lesion is morphologically represented by areas of simple atrophy and/or post-atrophic hyperplasia in which there is superimposed chronic inflammation. Using immunohistochemistry, the above authors have identified areas of high cell proliferation in which there is increased staining of $\Pi$-glutathione $s$ transferase (GSTP1) and bcl-2 along with decreased staining of the cyclin-dependent kinase inhibitor p27. The findings suggest that the cells of the secretory compartment in proliferative inflammatory atrophy have an immature secretory phenotype similar to that seen in cells of high-grade PIN and carcinoma. The authors have identified areas of atrophy merging into high-grade PIN within the same glands. They suggest that proliferative inflammatory atrophy may give rise to carcinoma, either directly or through high-grade PIN as an intermediary step. Clearly, further investigations are required 
to evaluate this hypothesis. It should be stressed however that proliferative inflammatory atrophy is a lesion which is not defined solely on the basis of the H\&E morphology but requires immunohistochemical markers of proliferation and differentiation for identification.

\section{Reactive atypia}

Epithelial atypia may be seen in association with acute or chronic prostatitis and may sometimes be present in association with prostatic ischemia (infarction). Reactive atypia can be confused with adenocarcinoma $^{43-45}$ (Figure 8). The glands in most cases of reactive atypia are atrophic and there may be some associated basal cell or transitional cell hyperplasia. In some cases, especially in ischemia, the epithelium may have a squamoid appearance and frank squamous or transitional metaplasia may be present (Figure 9). Mild to moderate nuclear enlargement is seen and sometimes nucleoli are prominent. The nucleolar enlargement may actually exceed that of adenocarcinoma.

The low-power architecture, presence of basal cells and degree of cytological atypia usually allow separation of reactive lesions from adenocarcinoma. However, adenocarcinoma may be present in areas of prostatitis and ischemia and as such diagnostic caution should prevail.

A special situation of reactive atypia is radiation effects. ${ }^{26,27}$ The degree of cytological atypia in irradiated prostates may be severe with enlarged, hyperchromatic nuclei and prominent nucleoli. The
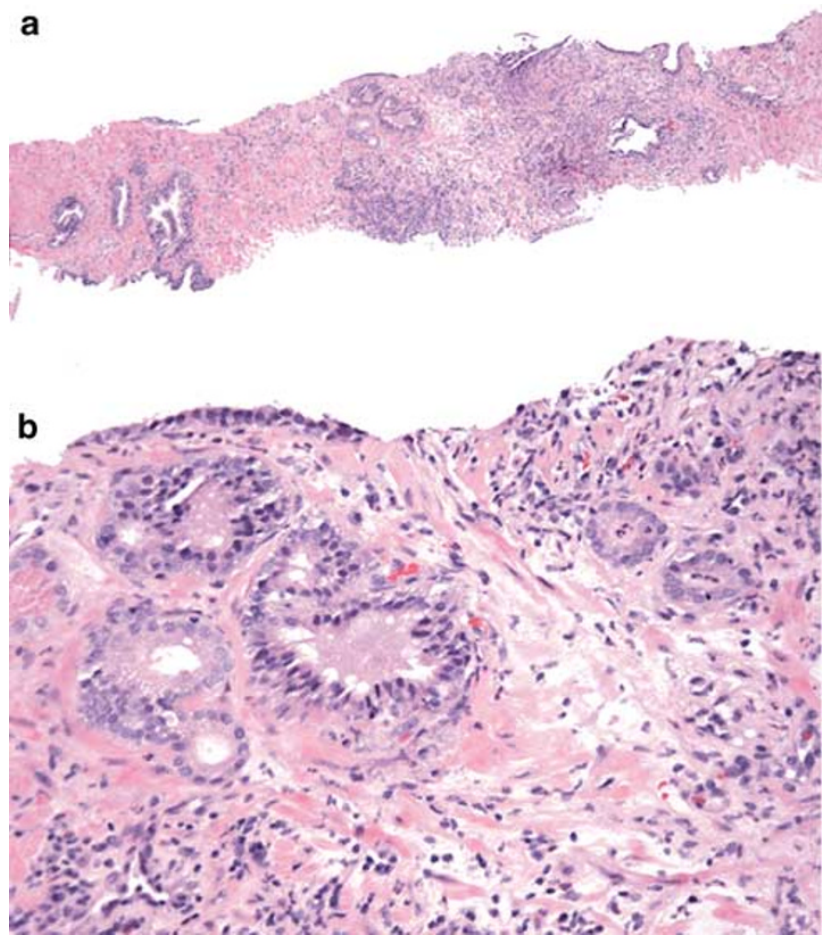

Figure 8 Active chronic prostatitis with reactive glandular atypia. (a) Low-power of needle biopsy. (b) High-power-note nuclear atypia in some glands. low-power architectural arrangement of the atypical glands is helpful in separating radiation atypia from residual adenocarcinoma. Other radiation-associated changes include prominent atrophy, transitional cell and squamous metaplasia, stromal fibrosis, edema and changes within prostatic arteries. In difficult cases, immunohistochemistry for high molecular weight keratin $(34 \beta \mathrm{E} 12)$ is invaluable in resolving the differential diagnosis.

\section{Mucinous metaplasia}

Mucin-producing cells are sometimes identified within prostatic glands, usually atrophic ones. ${ }^{22}$ As such, this process may enter the differential diagnosis of small acinar carcinoma. The lobular pattern of the associated atrophy usually points to the benign nature of this lesion (Figure 10). Individual mucous cells have a vacuolated appearance on H\&E and highlighted by mucicarmine and PAS stains. When there is florid mucinous metaplasia, especially in an apical location, confusion with Cowper's (bulbourethral) glands may occur. ${ }^{20,21}$
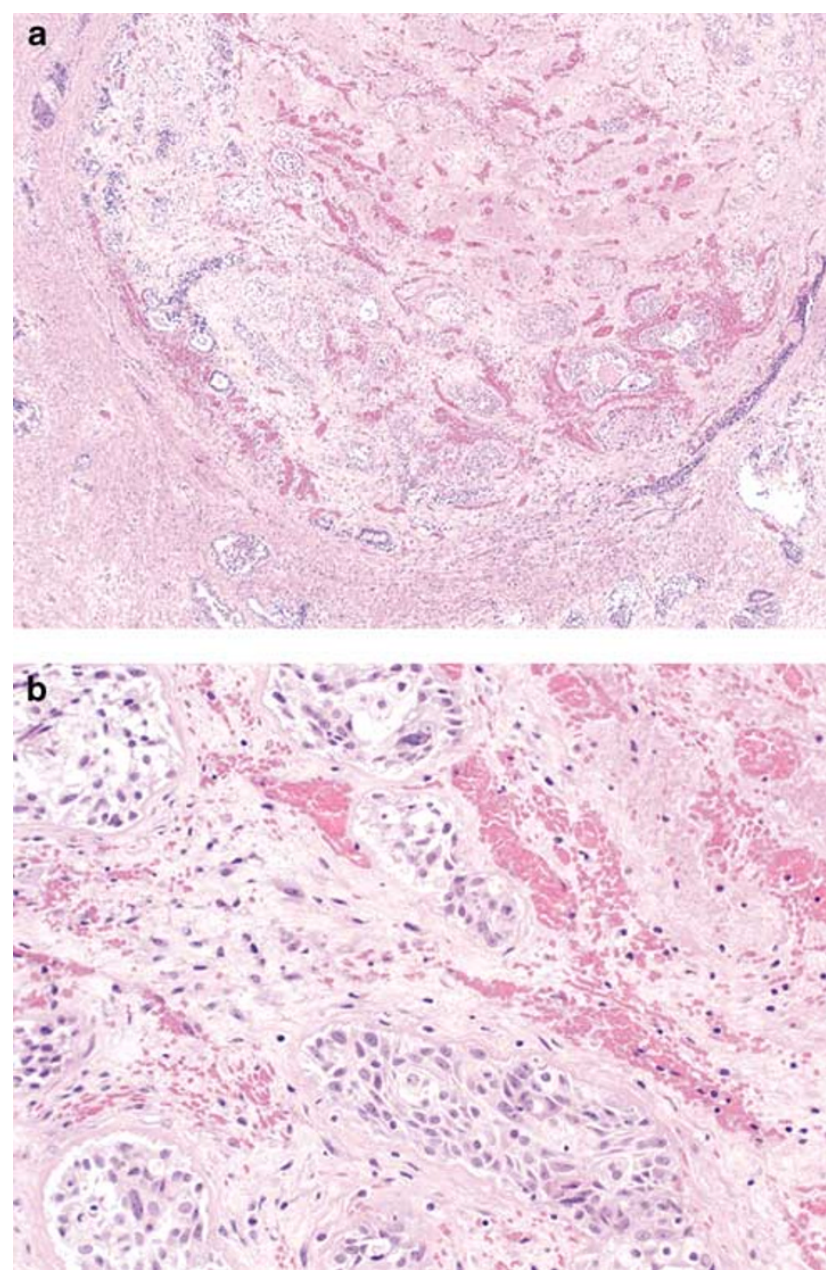

Figure 9 Prostatic infarct with reactive atypia. (a) Low power. (b) High power showing glands at edge of infarcted area-note squamoid features and nuclear atypicality. 


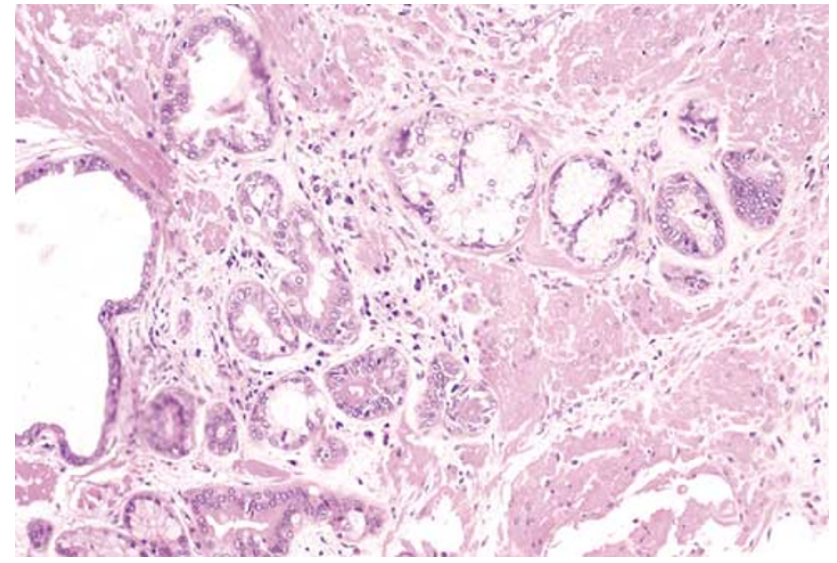

Figure 10 Atrophic prostate glands with focal mucinous metaplasia.

\section{Nephrogenic metaplasia (adenoma)}

Nephrogenic metaplasia (adenoma) is uncommonly encountered in the prostatic urethra, and subjacent prostatic tissue. ${ }^{4-49}$ It may be present as an exophytic (papillary) lesion or as a flat or nodular abnormality. In most instances, there has been a previous history of trauma, instrumentation or transurethral resection. Problems can arise when a prior transurethral resection has revealed adenocarcinoma.

Nephrogenic metaplasia displays exophytic papillary and tubulocystic elements. The latter may have a pseudoinvasive growth pattern (Figure 11). The acini of nephrogenic metaplasia are usually small and the cells have scant cytoplasm. Sometimes they may have more abundant clear cytoplasm. At least focally, the tubules may display cystic change and sometimes hobnail cells are identified. Commonly, the adjacent stroma is both edematous and inflamed.

The small size of the acini, cystic dilatation and inflamed stroma separate nephrogenic metaplasia from small acinar carcinoma. High molecular weight keratin (34 $\beta$ E12) is positive in some but not all cases of nephrogenic metaplasia. ${ }^{49}$ When positive, it is a helpful adjunctive test. The PSA and PAP stains are usually negative but there may be focal positivity of tubular cells and/or secretions. ${ }^{49}$

A recent study suggests that nephrogenic metaplasia (adenoma) is neither metaplastic nor neoplastic in nature. ${ }^{50}$ Molecular studies in the setting of transplantation suggest that this lesion is truly nephrogenic in origin and results from the implantation of renal tubular cells at sites of prior urothelial injury with subsequent proliferation of epithelial elements.

\section{Basal cell hyperplasia}

Basal cell hyperplasia is typically seen as part of the spectrum of nodular hyperplasia usually in samples from the transition zone. ${ }^{51-54}$ Recently, it has been
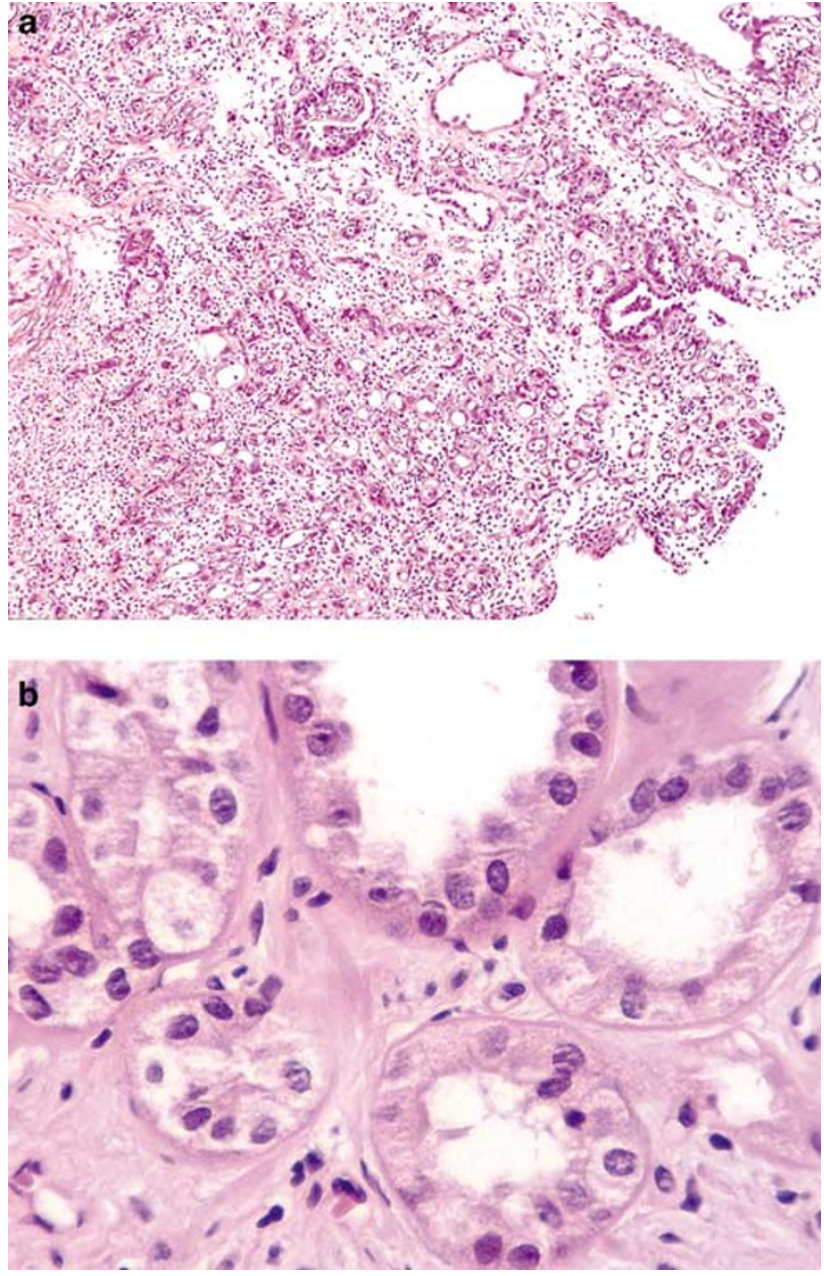

Figure 11 Nephrogenic metaplasia. (a) Low power. Note pseudoinfiltrative small tubules in an inflammatory background. (b) High power showing small acini with slight nuclear irregularity. This lesion may be confused with small acinar carcinoma.

recognized that basal cell hyperplasia may also affect the peripheral zone..$^{55}$ It is usually identified in transurethral resection specimens but may be encountered in needle biopsies (Figure 12). Basal cell hyperplasia may also occur in association with atrophy, usually in the setting of antiandrogen therapy. ${ }^{28-30}$ Basal cell hyperplasia may be confused with adenocarcinoma.

Basal cell hyperplasia is usually characterized by nodular expansion of uniform round glands associated with a cellular stroma. It may be complete or incomplete. ${ }^{15}$ There is a lack of secretory (luminal) cell differentiation in the complete form in which solid nests of dark-blue cells are present. In the incomplete form, there are residual small lumina lined by secretory cells with clear cytoplasm and these are surrounded by multiple layers of basal cells. In each type, the basal cells are dark and have scant cytoplasm and display round, oval or somewhat spindled hyperchromatic nuclei (Figure 12). Nucleoli are usually indistinct but in some 

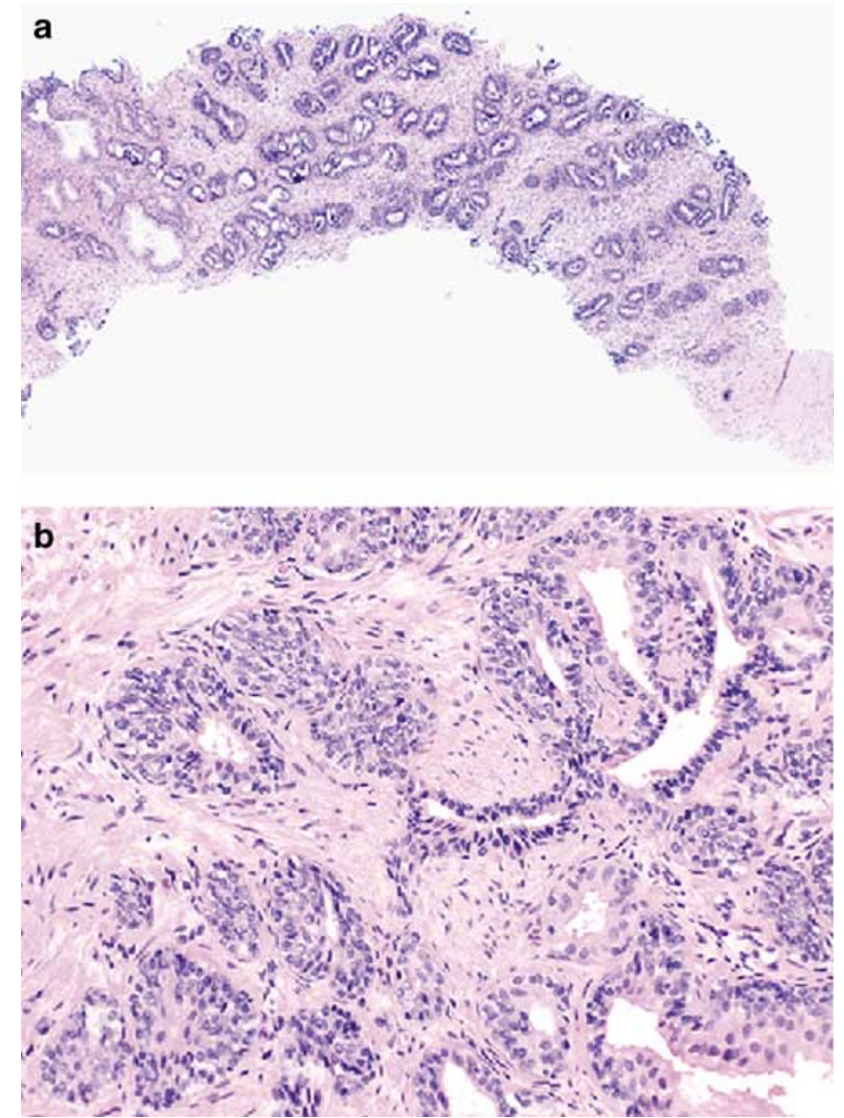

Figure 12 Basal cell hyperplasia in needle biopsy. (a) Low-power appearance showing prominent basophilic glands. (b) Highpower photomicrograph showing budding and proliferation of small, uniform, dark basal cells.

examples of the so-called atypical basal cell hyperplasia, nucleoli may be more prominent. ${ }^{53,56}$ Microcalcifications are present in up to half of the cases of basal cell hyperplasia. The adjacent stroma is often hypercellular and consists of proliferating fibroblasts and smooth muscle cells similar to those seen in usual nodular hyperplasia.

Basal cell hyperplasia is readily separated from adenocarcinoma in most cases, especially in transurethral resectate and prostatectomy specimens. The nodular arrangement, association with ordinary nodular hyperplasia, cellular uniformity and lack of prominent nucleoli serve to separate this condition from cancer. It may be more difficult however in small biopsies in which part of a focus of basal cell hyperplasia is only partially represented. In such cases, the distinction relies on the identification of uniform cytological and nuclear features and in some instances may require immunohistochemical staining for high molecular weight keratin $(34 \beta \mathrm{E} 12) .{ }^{52}$

Benign nodular hyperplasia, small gland pattern Benign nodular hyperplasia of prostate can have a variety of morphologies including predominantly stromal, mixed glandular and stromal, and predo-

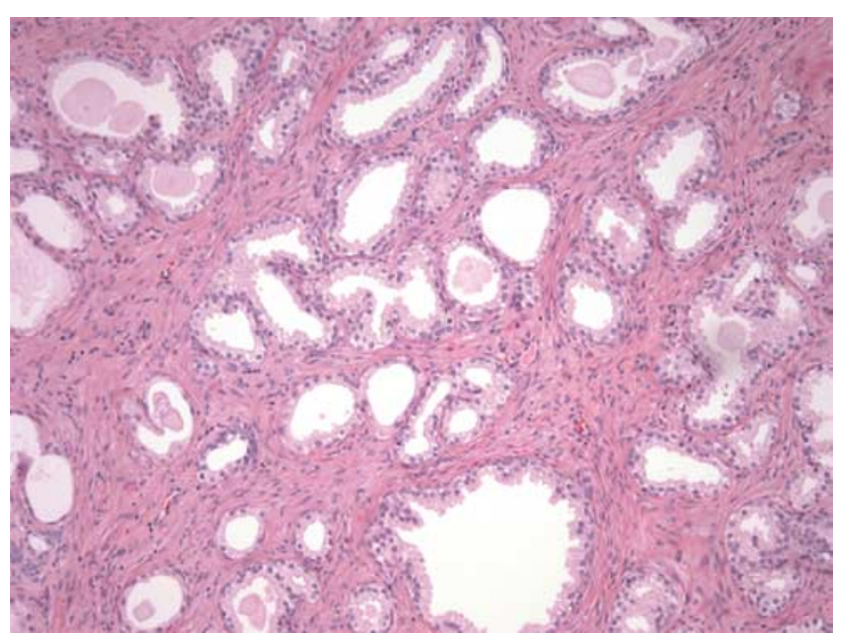

Figure 13 Small gland pattern of benign nodular hyperplasia. Note several small- to medium-sized, irregular acini embedded in a cellular stroma.

minantly glandular growth patterns. ${ }^{9,15}$ The glandular elements usually consist of medium to large acini, often showing luminal papillae. Occasionally, areas of nodular hyperplasia are composed of mainly small to medium sized, closely packed acini with rounded lumens.

Usually basal cells are readily identified and small amounts of intervening cellular stroma are seen. The nodular circumscription, uniform architecture, presence of basal cells and intervening stroma serve to separate this proliferative pattern from low-grade (Gleason patterns 1,2) adenocarcinoma (Figure 13).

It is probably more common for adenocarcinoma to mimic benign nodular hyperplasia than the converse. The pseudohyperplastic pattern of adenocarcinoma is composed of medium to large acini that may have a somewhat nodular appearance on low power. ${ }^{57,58}$ This form of carcinoma can be deceptively bland and may only be suspected when there is a subtle disruption of the normal gland/ stroma relationship on low power. This observation can be quite difficult in thin core biopsies. On higher power, there is an absence of basal cells and the typical nuclear features of adenocarcinoma are present. The cells comprising this lesion are usually high cuboidal to columnar cells with abundant apical, often clear cytoplasm. These cells resemble the appearance of the secretory cell compartment in benign nodular hyperplasia aside from their nuclear features. The $34 \beta$ E12 stain is invaluable in confirming a diagnosis of pseudohyperplastic adenocarcinoma.

\section{Sclerosing adenosis}

The term sclerosing adenosis of the prostate was first used by Young and Clement in 1987 to describe an unusual prostatic proliferative lesion which resembled to some extent sclerosing adenosis of breast. ${ }^{59}$ There had been an earlier report in which 
the term adenomatoid tumor was used. ${ }^{60}$ Sclerosing adenosis is an uncommon lesion largely restricted to the transition zone and is generally an incidental finding in transurethral resectates or radical prostatectomy specimens. It is rarely seen in needle biopsies. A few series of sclerosing adenosis cases have been reported. ${ }^{61-63}$

Sclerosing adenosis is characterized by a more or less circumscribed proliferation of variably sized, often small glands embedded in a cellular and often edematous stroma (Figure 14). Sometimes the lightly basophilic stroma is recognized on low power. Tiny microacini, cords, solid clusters and single cells are seen. A double layer is present but may be difficult to appreciate with the H\&E stain. The lining cells often have open nuclear chromatin with inconspicuous nucleoli although prominent nucleoli may be focally present. Glandular lumens may contain crystalloids or occasionally acid mucin. A characteristic feature is the present of a thick eosinophilic basement membrane around at least some glands.

Sclerosing adenosis is unique in that the basal cells in this condition undergo myoepithelial metaplasia and show coexpression of both high molecular weight cytokeratin and muscle-specific actin $\left(\right.$ HHF-35) ${ }^{63}$ (Figure 14). S100 protein is also positive in these cells. The myoepithelial differentiation has been confirmed by electron microscopic studies.

The key features distinguishing sclerosing adenosis from adenocarcinoma include the variation in gland size and shape, thickened basement membranes and cellular stroma. Immunohistochemistry for high molecular weight keratin (34 $\beta \mathrm{E} 12)$ and actin can be used in problematic cases.

\section{Verumontanum mucosal gland hyperplasia}

Verumontanum mucosal gland hyperplasia is identified as an incidental finding in radical prostatectomy specimens. ${ }^{64}$ In all, $14 \%$ of 30 radical prostatectomy specimens in one series contained one or more foci of hyperplastic verumontanum mucosal glands. This process is rarely encountered in needle biopsy specimens. ${ }^{65}$ It is characterized by relatively uniform, closely packed, round glands containing numerous corpora amylacea which may have a red or orange-brown coloration (Figure 15). Basal cells are usually identified and there is a lack of nuclear features of malignancy. In particular, prominent nucleoli are not seen. Lipofuscin pigment may be present within the cytoplasm of
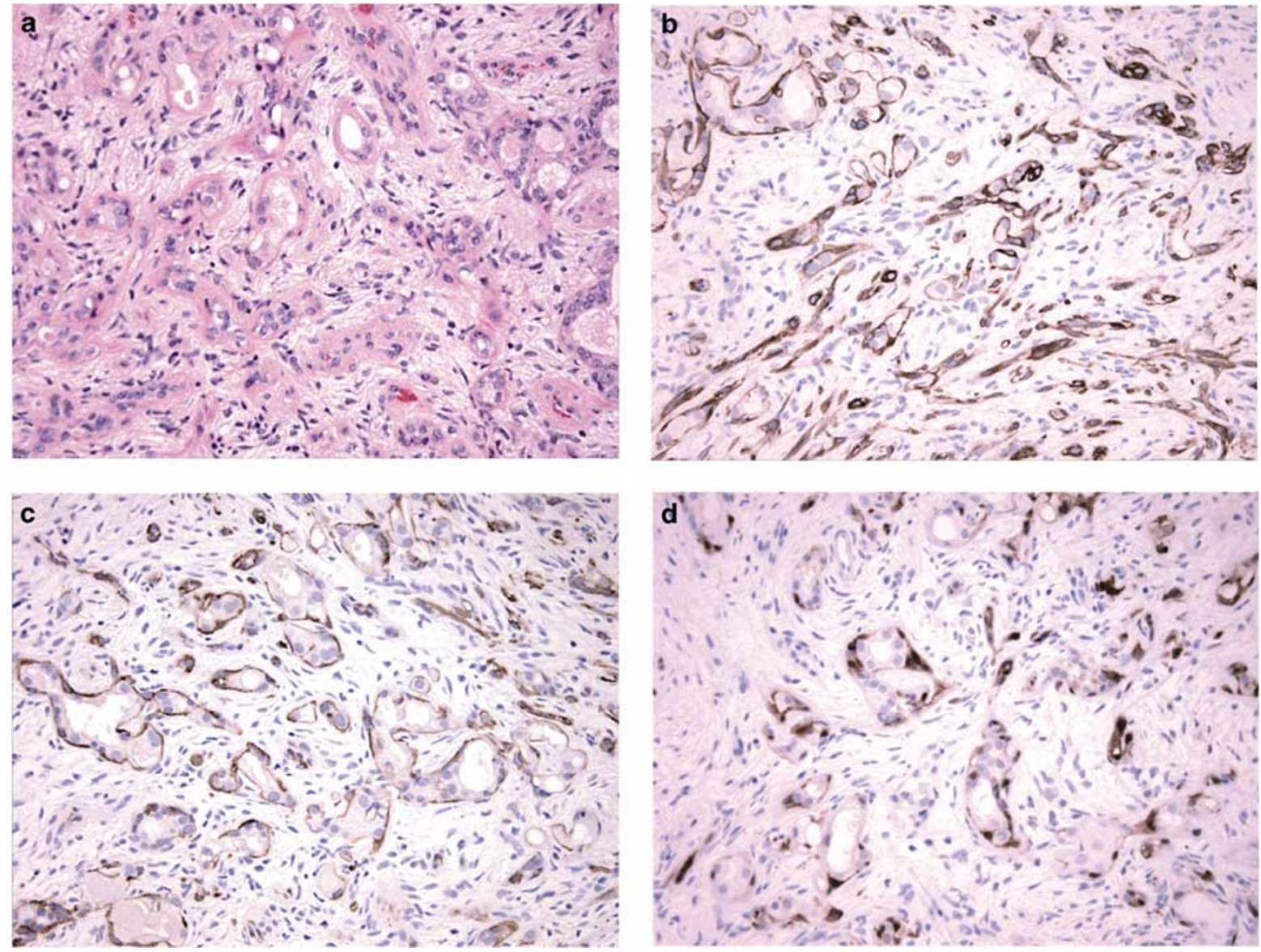

Figure 14 Sclerosing adenosis of prostate. (a) H\&E appearance showing small glands with thick basement membranes embedded in cellular fibrous stroma. (b) High molecular weight keratin staining (34 $\beta$ E12) demonstrating positive basal cells. (c) HHF35 (musclespecific actin) staining in basal cells indicating myoepithelial metaplasia. (d) S100 positivity in basal cells. 
glandular cells. Prostatic urethral tissue is often seen nearby and islands of transitional cell epithelium may be present in or adjacent to the proliferating verumontanum glands. The suburethral location, acinar and cellular uniformity, basal cells and prominent corpora amylacea allow separation of this entity from low-grade adenocarcinoma. Recently verumontanum mucosal gland hyperplasia has been associated with atypical adenomatous hyperplasia in a radical prostatectomy series. ${ }^{66}$

\section{Hyperplasia of mesonephric glands}

Mesonephric gland remnants are rarely identified in prostatic specimens. ${ }^{67-71}$ In a series of close to 700 transurethral resectates, $0.6 \%$ contained mesonephric remnants. ${ }^{70}$ Mesonephric gland remnants occasionally undergo hyperplasia and may be confused with adenocarcinoma. Gikas et al identified two cases in transurethral resection specimens that were interpreted as adenocarcinoma which in one instance led to an unnecessary radical prostatectomy. ${ }^{67}$ The hyperplastic mesonephric glands are typically small and may have an infiltrative appearance (Figure 16). Sometimes tubular dilatation, epithelial tufting and micropa-
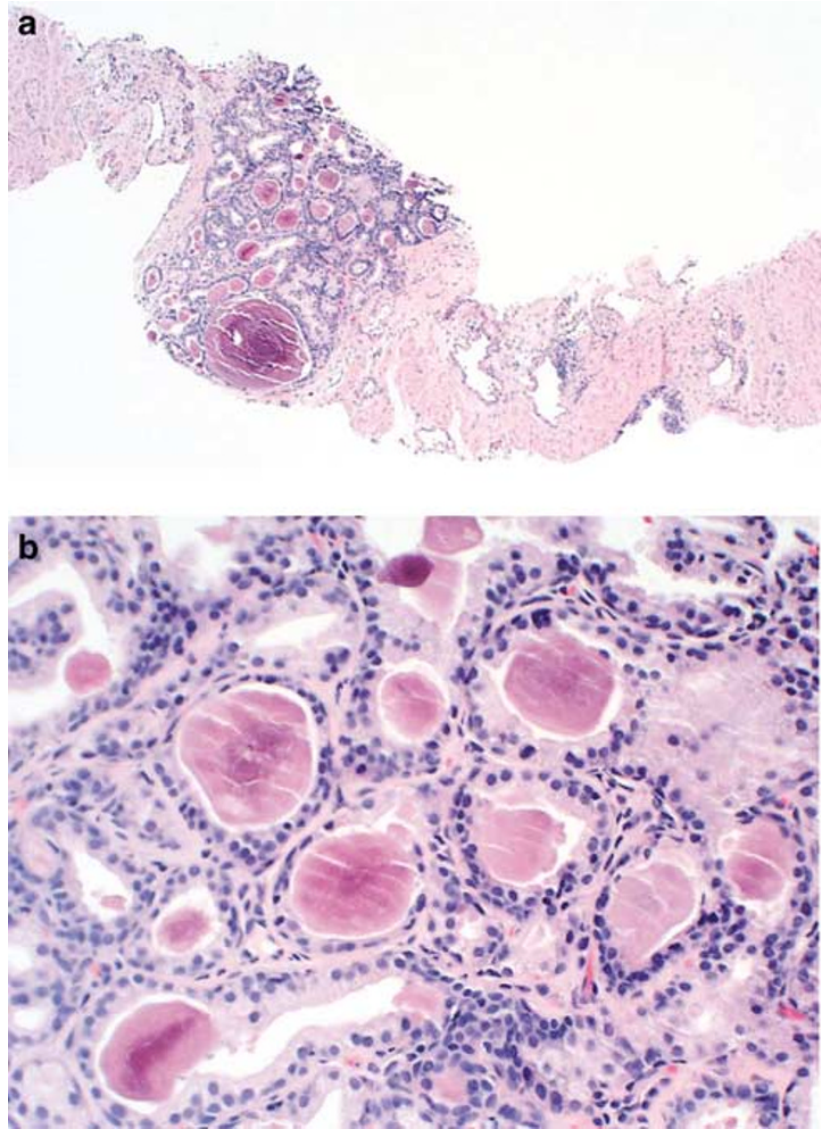

Figure 15 Verumontanum mucosal gland hyperplasia. (a) Lowpower appearance in needle biopsy. (b) High-power appearance showing tightly packed small acini with prominent corpora amylacea. pillary formations are seen. They may demonstrate perineural spread and extraprostatic extension. Mesonephric glands are lined by a single layer of cuboidal cells. Typically, the small glands contain a dense eosinophilic luminal substance which contrasts with the loose granular eosinophilic material typical of small acinar carcinoma (Figure 16). Immunohistochemistry may be helpful in difficult cases. The glands of mesonephric hyperplasia stain negatively for PSA and PAP and often positively for high molecular weight cytokeratin (34 $\beta$ E12) in contrast to adenocarcinoma which lacks $34 \beta \mathrm{E} 12$ basal cells.

\section{Atypical adenomatous hyperplasia (adenosis)}

Atypical adenomatous hyperplasia (AAH) is a proliferative lesion characterized by crowded small acini, usually forming well circumscribed nodules which often simulate the small gland pattern of carcinoma. ${ }^{72-78}$ While many authors use the term
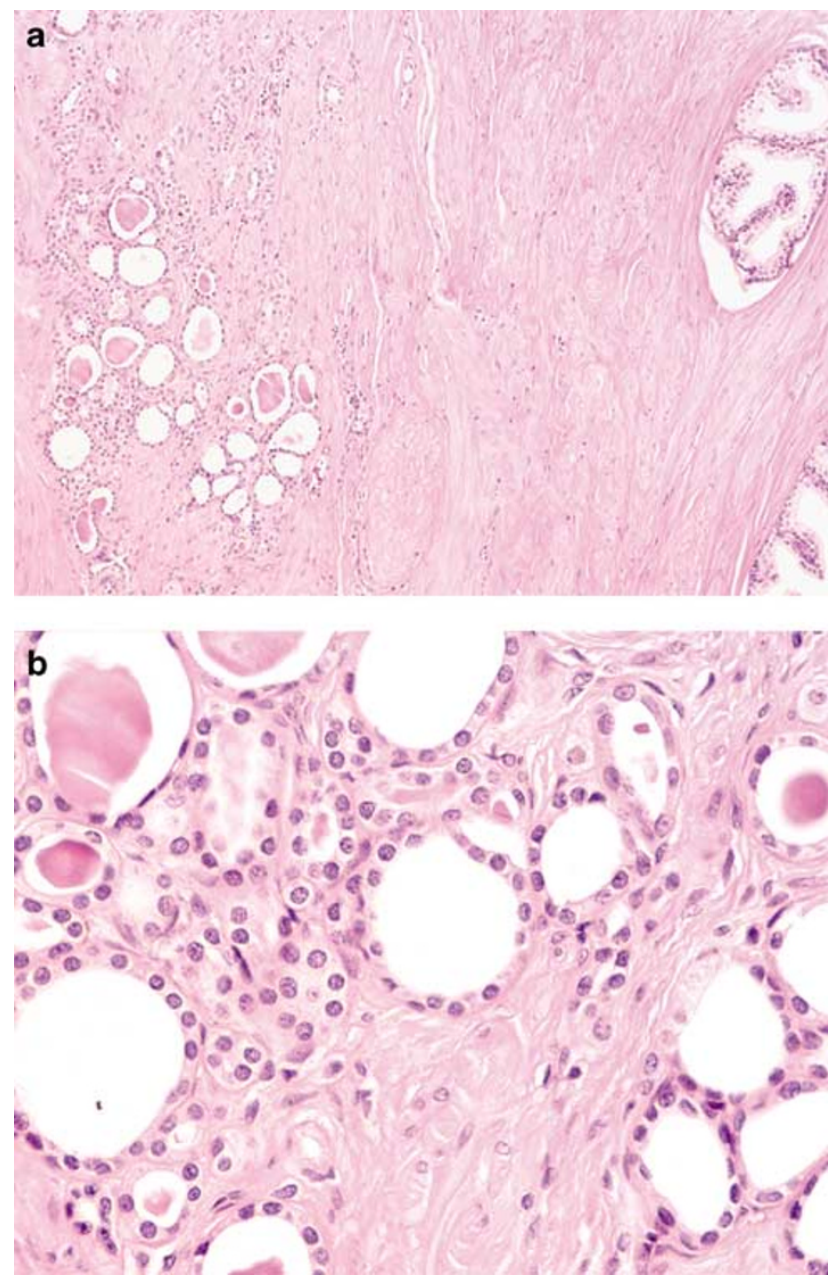

Figure 16 Hyperplasia of mesonephric glands. (a) Low power. Note prostatic glands on right side and mesonephric glands on left. (b) High-power photomicrograph. Note small acini, some of which are cystically dilated and some containing colloid-like secretions. 
'atypical adenomatous hyperplasia' others prefer the rubric 'adenosis' ${ }^{79-83} \mathrm{AAH}$ is a well-defined entity but the term 'adenosis' has been used more loosely, even to the extent that some examples of adenosis have been interpreted by experts as adenocarcinoma. ${ }^{84}$

AAH has been identified in $1.5-19.6 \%$ of transurethral resectates and in up to $33 \%$ of radical prostatectomy specimens. $^{9}$ It is uncommon in needle biopsy specimens but occasionally occurs. ${ }^{82}$

Most evidence associating AAH with carcinoma is circumstantial. $^{9,75,78}$ AAH has a predilection for the transition zone and morphologically simulates low grade (Gleason 1,2) carcinoma. Examples of small acinar carcinoma arising in relationship to AAH have been reported. Additionally, the age of patients with AAH is usually $5-10$ years, less than those with carcinoma.

The basal cell-specific keratin stain shows a discontinuous pattern which is intermediate between the continuous pattern of normal prostate and the absence of basal cells in carcinoma. ${ }^{8,74,85}$ Studies with tridiated thymidine, immunohistochemistry for proliferation markers (Ki67/M1B-1) and silver staining of nucleolar-organizer regions suggest that AAH has a proliferation rate between benign prostate hyperplasia and low-grade carcinoma. ${ }^{86-88}$ Recent molecular and phenotypic studies suggest a possible linkage between AAH and carcinoma in the minority of cases. ${ }^{89,90}$

While circumstantial evidence exists, there is lack of proof of a relationship between AAH and adenocarcinoma. ${ }^{9}$ It has been suggested that AAH is a precursor of some low-grade transition zone carcinomas but the lack of an increased prevalence of AAH in prostate glands with transition zone carcinoma argues against this hypothesis. ${ }^{9}$ Clearly, there is less evidence linking AAH to carcinoma than there is for high-grade PIN and cancer. ${ }^{9,75}$

The major importance of AAH is its potential for being misdiagnosed as adenocarcinoma. Foci of AAH are usually less than $5 \mathrm{~mm}$ across and are characterized by a proliferation of relatively small uniform acini, often within or adjacent to typical hyperplastic nodules (Figure 17). Sometimes there is a prominent perinodular distribution of the abnormal glands. The low-power architecture is reminiscent of Gleason patterns 1 and 2 carcinoma. AAH usually has a pushing rather than infiltrating border but may show a limited degree of infiltration (Figure 18). Individual glands are closely packed but separate and show no evidence of fusion. They show some variation in size and shape and are lined by cuboidal to low columnar cells with moderate to abundant clear or lightly eosinophilic cytoplasm. Basal cells are usually recognized at least focally. The luminal borders are often irregular and somewhat serrated in contrast to the rigid borders that typify small acinar carcinoma. The lumens are often empty but may contain corpora amylacea and in some
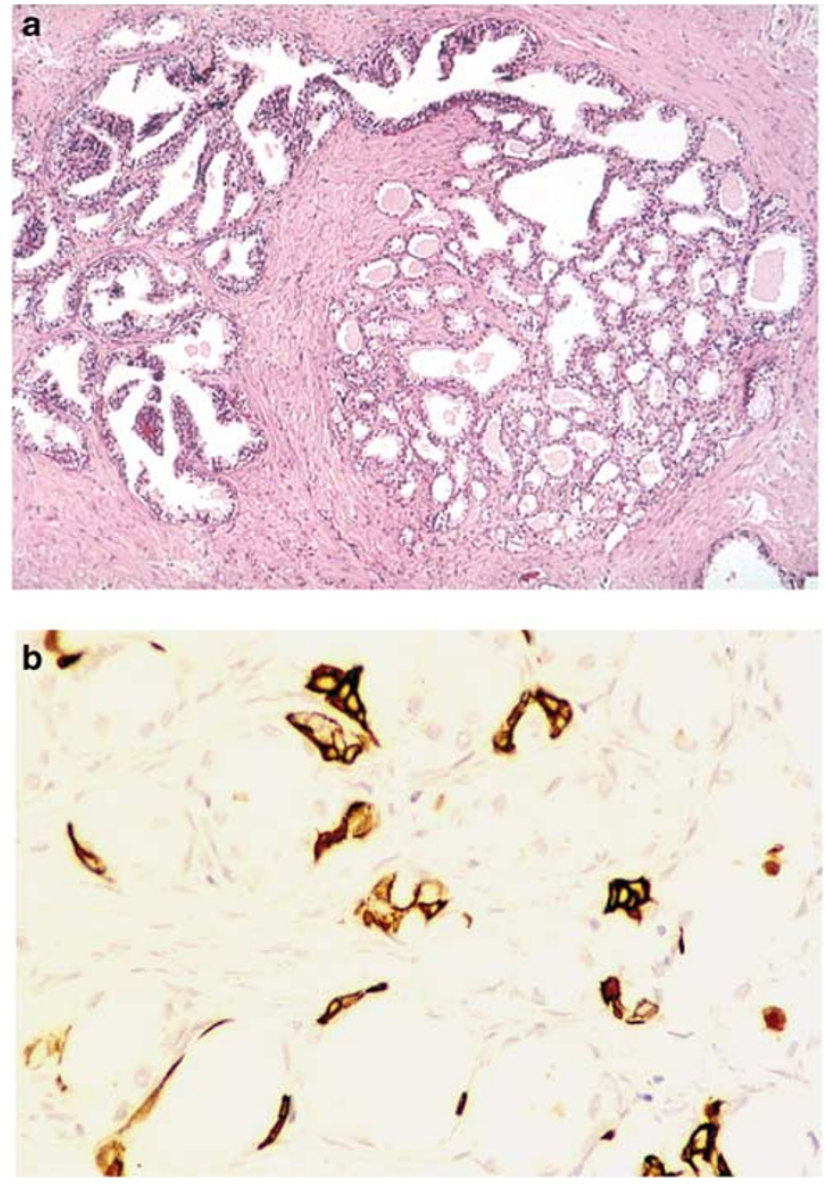

Figure 17 Atypical adenomatous hyperplasia (adenosis). (a) Lowpower photomicrograph showing apparent budding of small regular acini off a parent duct. Note close relationship between the small gland proliferation and the benign overall nodule. (b) Discontinuous pattern of $34 \beta \mathrm{E} 12$ staining characteristic of atypical adenomatous hyperplasia (adenosis).

instances luminal eosinophilic crystalloids. ${ }^{74,81}$ Occasionally, basophilic luminal mucus may be seen. ${ }^{91,92}$ There is usually no stromal response but occasionally, a fibroblastic response is identified which leads to overlap with the pattern of sclerosing adenosis. ${ }^{59-63}$

The nuclei of atypical adenomatous hyperplasia are round to oval and there is uniform fine chromatin. ${ }^{74}$ Nucleoli may be present but they are generally small. Uncommonly, enlarged nucleoli $(>1 \mu \mathrm{m})$ are identified in a subset of cells. ${ }^{74}$

By immunohistochemistry, the glands of $\mathrm{AAH}$ exhibit strong positivity for PSA and PAP and there is typically a discontinuous basal cell pattern with the $34 \beta$ E12 stain (Figure 17).

The most important features in separating $\mathrm{AAH}$ from adenocarcinoma is the lack of significantly enlarged nucleoli and the presence of a fragmented basal cell layer. A comparison between high- and low-grade carcinoma is shown in Table 4.

From a clinical perspective, AAH should be considered as a benign lesion and patients followed 

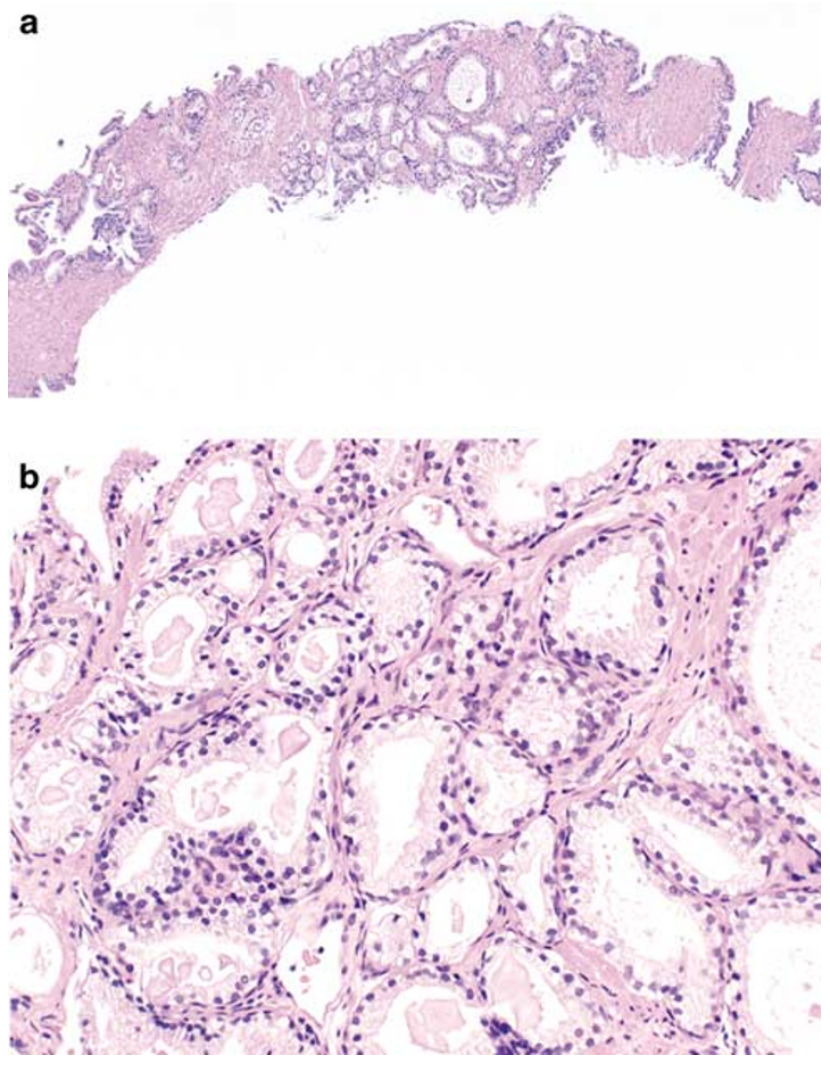

Figure 18 (a) Atypical adenomatous hyperplasia (adenosis) in needle biopsy. Note central proliferating small gland process. (b) High-power photomicrograph showing some variation in size and shape of small acini. Basal cells are maintained and there is no significant nuclear atypia.

conservatively. The term should not be used as a 'wastebasket' for small glandular lesions that are difficult to classify or for suspicious atypical small gland proliferations (atypical small acinar proliferation [ASAP], glandular atypia), just below the threshold of adenocarcinoma. ${ }^{9}$

\section{Large Gland Pattern}

\section{Clear cell cribriform hyperplasia}

Benign nodular hyperplasia occasionally displays areas of prominent cribriform glands. Rarely, the cribriform process dominates the histologic picture. ${ }^{93,94}$ Cribriform hyperplasia is characterized by a crowded proliferation of complex glands without cytologic atypia. In most instances, the cribriform glands have clear cytoplasm and uniform round lumina. This lesion generally has a low-power nodular appearance and intervening cellular stroma is seen (Figure 19). The cells comprising the central cribriform areas are cuboidal to low columnar secretory-type cells with uniform round nuclei and clear cytoplasm. They lack nuclear atypia and nucleolar enlargement. Basal cells are prominently displayed around the periphery.

Cribriform hyperplasia enters the differential diagnosis of both prostatic intraepithelial neoplasia
Table 4 Atypical adenomatous hyperplasia vs well-differentiated adenocarcinoma

\begin{tabular}{|c|c|c|}
\hline & $\begin{array}{l}\text { Atypical } \\
\text { adenomatous } \\
\text { hyperplasia }\end{array}$ & $\begin{array}{l}\text { Carcinoma } \\
\text { (Gleason grades } 1 \\
\text { and 2) }\end{array}$ \\
\hline \multicolumn{3}{|c|}{ Architectural and associated features } \\
\hline Low power & $\begin{array}{l}\text { Circumscribed or } \\
\text { limited } \\
\text { infiltration }\end{array}$ & $\begin{array}{l}\text { Circumscribed or } \\
\text { limited } \\
\text { infiltration }\end{array}$ \\
\hline Lesion size & Variable & Variable \\
\hline Gland size & Variable & Less variable \\
\hline Gland shape & Variable & Less variable \\
\hline Crystalloids & Infrequent & Frequent \\
\hline $\begin{array}{l}\text { Corpora } \\
\text { amylacea }\end{array}$ & Frequent & Infrequent \\
\hline $\begin{array}{l}\text { Basophilic } \\
\text { mucin }\end{array}$ & Infrequent & Frequent \\
\hline \multicolumn{3}{|l|}{ Nuclear features } \\
\hline $\begin{array}{l}\text { Nuclear size } \\
\text { variation }\end{array}$ & Less variable & Variable \\
\hline Chromatin & Uniform/granular & Uniform or variabl \\
\hline $\begin{array}{l}\text { Parachromatin } \\
\text { clearing }\end{array}$ & Infrequent & Frequent \\
\hline Nucleoli & Inconspicuous & Prominent \\
\hline \multicolumn{3}{|l|}{ Basal cell layer } \\
\hline H\&E stain & Inconspicuous & Absent \\
\hline $\begin{array}{l}\text { HMWK (34 } \beta \text { E12) } \\
\text { stain }\end{array}$ & Fragmented & Virtually absent \\
\hline
\end{tabular}

Modified from Bostwick et al. ${ }^{5}$

and cribriform adenocarcinoma. The distinction of cribriform hyperplasia from cribriform carcinoma is based on the 'low power' nodularity, cellular stroma, presence of basal cells and lack of significant cytologic atypia.

\section{Adenoid cystic-like basal cell hyperplasia}

While most forms of basal cell hyperplasia are characterized by relatively small nests of basal cells, the incomplete form of basal cell hyperplasia may be composed of medium to large glands with a complex cribriform pattern, sometimes with cyst formation and squamous metaplasia. ${ }^{9,52,95,96}$ Such a process rarely enters the differential diagnosis of cribriform carcinoma. Some of these cases have been termed adenoid basal cell tumor or even basal cell carcinoma (Figure 20). The presence of typical areas of basal cell hyperplasia, lack of significant infiltration and absence of cytological atypia favor adenoid cystic-like basal cell hyperplasia over cribriform carcinoma.

\section{Reactive atypia in large glands}

Medium to large glands may display reactive atypia in the setting of inflammation, ischemia and radiation. ${ }^{9,43-45}$ Such processes may lead to glandular distortion and nuclear atypia which sometimes results in a pattern that may be confused with prostatic intraepithelial neoplasia (PIN) and large gland patterns of adenocarcinoma. The most helpful features to distinguish reactive atypia from 

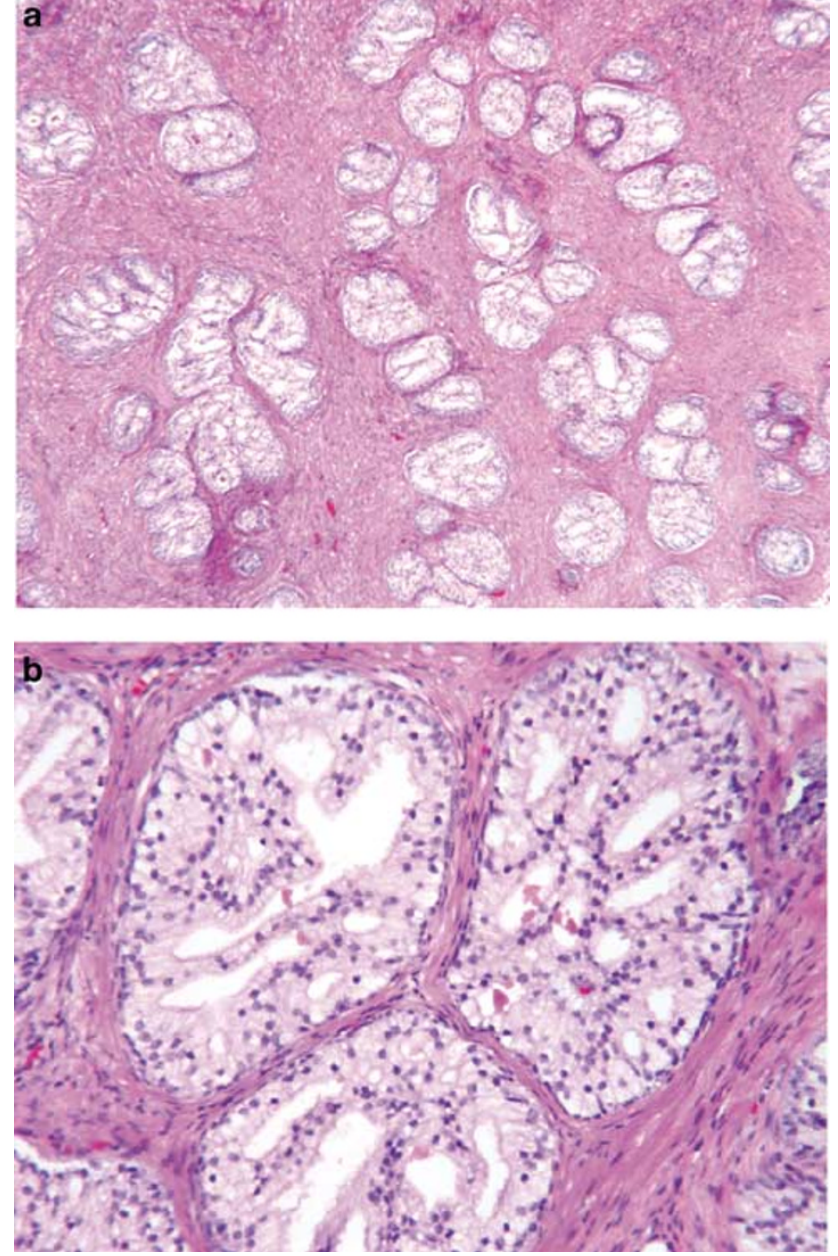

Figure 19 Clear cell cribriform hyperplasia. (a) Note low-power nodularity and uniform distribution of cribriform glands in cellular stroma. (b) High-power photomicrograph showing uniform cribriform glands with abundant clear cytoplasm. Basal cells are apparent. No significant nuclear atypia is seen.

malignancy is the recognition of the associated inciting factor such as inflammation, infarction or radiation, and the maintenance of the basal cell compartment. The atypia associated with reactive conditions may result in nuclei that appear hyperchromatic and somewhat degenerate. In some cases, the nucleolar enlargement associated with the reactive state may be more prominent and more uniform than that seen with adenocarcinoma. The low-power architecture and presence of a residual basal cell layer sometimes requiring confirmation with the $34 \beta \mathrm{E} 12$ stain are the best clues to the benign nature of this condition.

\section{Fused Gland Pattern}

\section{Paraganglion}

Paraganglionic tissue may be encountered within prostatic and periprostatic tissue, usually the latter. ${ }^{97-99}$ Paraganglia are characterized by small, solid
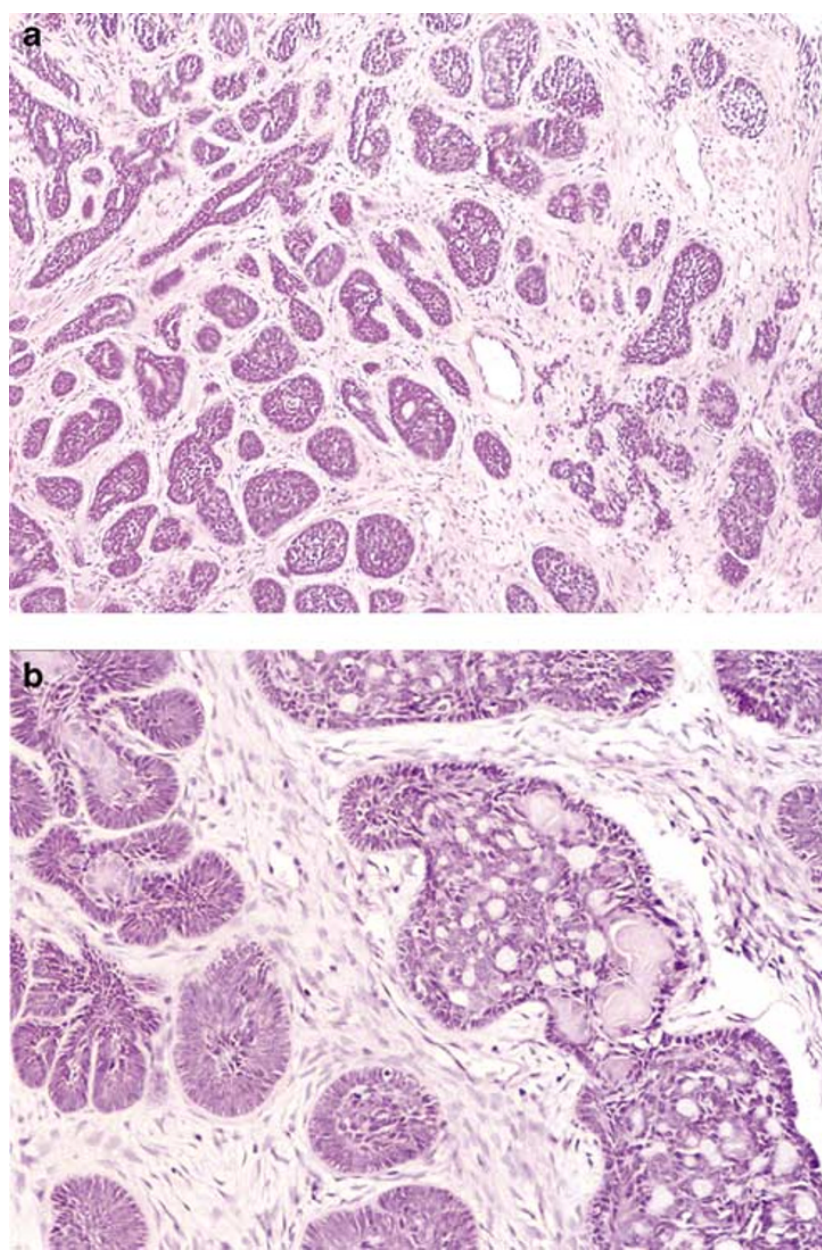

Figure 20 Adenoid cystic-like basal cell hyperplasia. (a) Lowpower photomicrograph showing a rounded collection of large basaloid nests embedded in loose stroma. (b) Medium-power photomicrograph showing proliferation of basaloid nests and cribriform structures with focal dense amorphous material.

nests of cells with clear or amphophilic cytoplasm, often with a 'zellballen' arrangement. There is a delicate background network of capillaries. The nuclei are often hyperchromatic but nucleoli and other features of adenocarcinoma are not seen. The islands of paraganglionic tissue are separated by fibrous stroma. Paraganglionic tissue can simulate the fused gland pattern of adenocarcinoma (Gleason 4) (Figure 21). If the cytoplasm of the paraganglionic tissue is amphophilic, it may look like Gleason pattern $4 \mathrm{~A}$ and if clear may look like Gleason pattern 4B. Cases in needles biopsies are quite rare. A more common issue is the overinterpretation of extraprostatic paraganglionic tissue in radical prostatectomy specimens leading to spurious overstaging of organconfined cancer. Additionally, the interpretation of paraganglionic tissue as adenocarcinoma may lead to a grading inaccuracy. When a Gleason grade 3 tumor is encountered and accompanying paraganglionic tissue is interpreted as Gleason grade 4 tumor, the resultant score would be inaccurately 

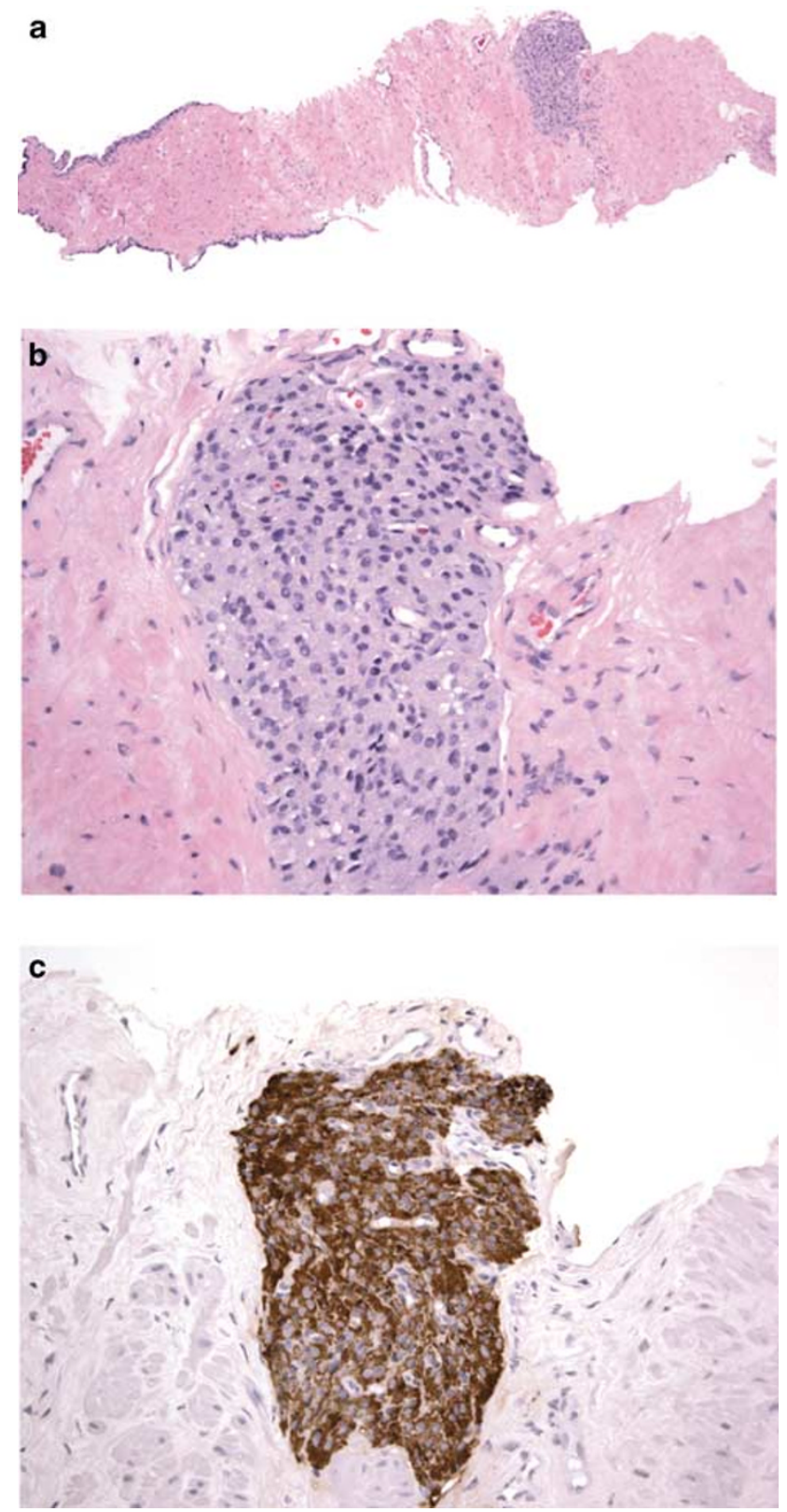

Figure 21 Prostatic paraganglion. (a) Needle biopsy showing solid amphophilic area. (b) High-power photomicrograph showing rounded amphophilic cellular mass without significant atypia. (c) Positive chromogranin stain.

recorded as 7 instead of the correct score of 6 . In problematic cases, special stains determining prostatic origin (PSA, PAP) and stains for neuroendocrine cells (chromogranin, synaptophysin) should be employed (Figure 21).

\section{Xanthogranulomatous prostatitis (xanthoma)}

Collections of lipid-laden macrophages in the prostate may cause diagnostic confusion with the hypernephroid pattern of adenocarcinoma (Gleason 4B) ${ }^{100,101}$ (Figure 22). Xanthomatous histiocytes usually have small uniform nuclei within incon-

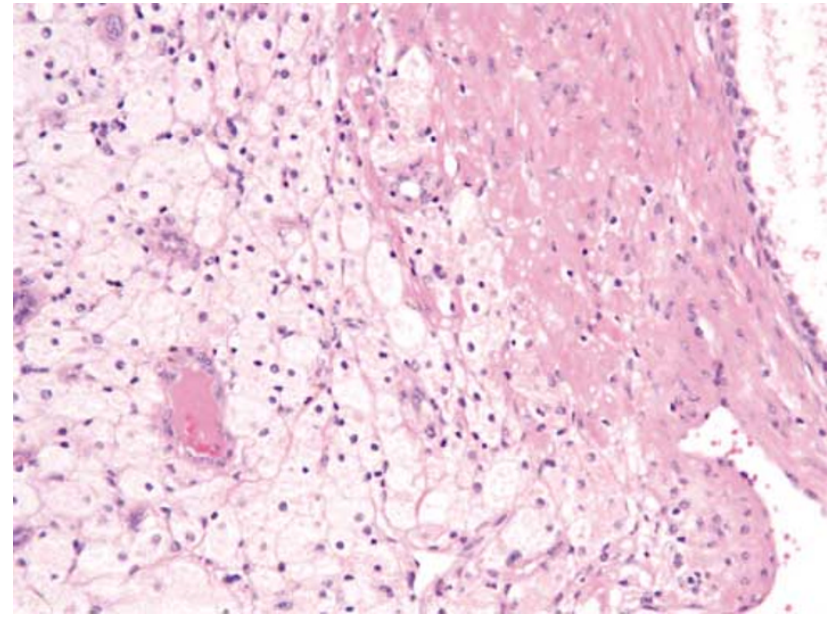

Figure 22 Xanthogranulomatous inflammation (xanthoma) of prostate. Note collection of uniform cells with small dark nuclei and abundant clear to foamy cytoplasm. This lesion may be confused with the hypernephroid pattern of prostatic adenocarcinoma (Gleason 4B).

spicuous nucleoli and are commonly admixed with other types of inflammatory cells. In some instances, there is almost a pure population of foam cells which can lead to considerable diagnostic confusion. The problem is compounded by the fact that some hypernephroid carcinomas do not show the typical nuclear features of malignancy. They may have small dark nuclei without prominent nucleoli. In rare cases, immunohistochemistry utilizing stains for epithelial and prostatic cells (cytokeratin, PSA, PAP) and histiocytes (CD68) is required to resolve the diagnostic confusion.

\section{Malakoplakia}

Malakoplakia of the prostate is a rare infiltrative lesion characterized by diffuse sheets of histiocytes, usually admixed with other inflammatory cells including lymphocytes, plasma cells and neutrophils. ${ }^{102-106}$ In the early phase of malakoplakia when von Hansemann histiocytes predominate, the lesion may simulate carcinoma, especially Gleason pattern 4B. The lack of any acinar differentiation and admixed inflammatory infiltrate along with the typical Michaelis-Gutmann bodies will lead to a correct diagnosis (Figure 23). The absence of cytokeratins and prostatic epithelial markers along with the presence of CD68 staining may resolve difficult diagnostic problems.

\section{Solid Pattern}

\section{Ordinary prostatitis}

Occasionally, needle biopsies with prostatitis of the usual type may cause diagnostic problems. ${ }^{107-109}$ This is especially true when there is poor preservation and mechanical (crush) artifacts (Figure 24). In some cases, immunohistochemical stains (keratins, 


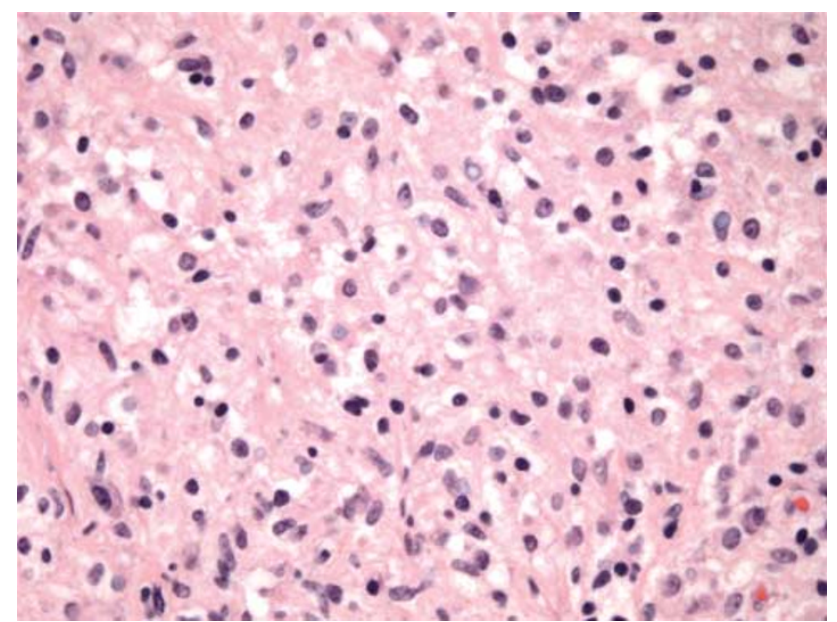

Figure 23 Prostatic malakoplakia—note sea of pink histiocytic cells (Von Hansemann cells) with occasional Michaelis-Gutmann bodies.

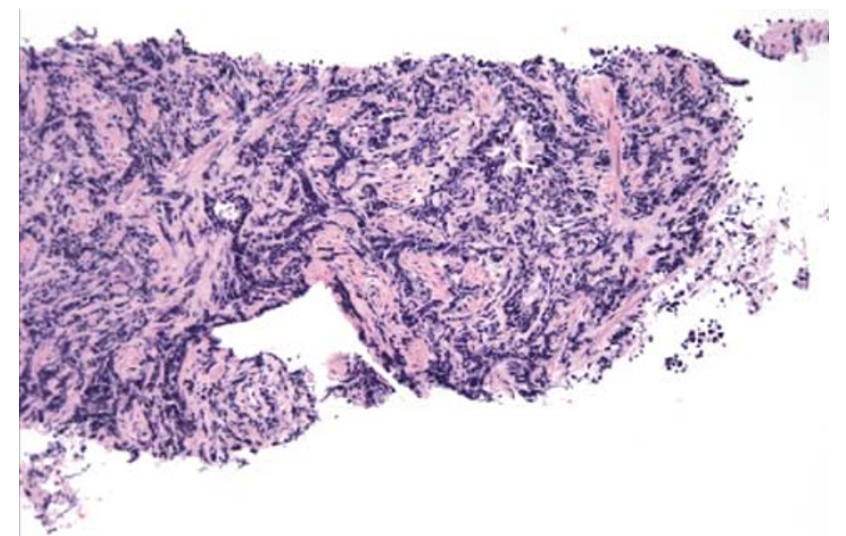

Figure 24 Crushed and inflamed prostatic tissue simulating solid carcinoma.

leukocyte common antigens) are required in order to resolve a differential diagnosis.

\section{Non-specific granulomatous prostatitis}

Granulomatous prostatitis commonly results in a prostate gland that feels firm to hard and clinically simulates carcinoma. ${ }^{110,111}$ In biopsy samples, especially needle biopsies, florid nonspecific granulomatous prostatitis may simulate carcinoma. ${ }^{112,113}$ The association of the inflammation with ducts may not be seen and when the inflammatory process is diffuse, it may raise the suspicion of high-grade (Gleason 5) carcinoma (Figure 25). The problem is amplified if poor preservation or mechanical artifacts are present. The recognition of the inflammatory nature of the cells along with the association of giant cells and fibrosis are helpful features. In difficult cases, immunohistochemistry for cytokeratins, prostatic epithelial markers and lymphohistiocytic markers may be used (Figure 26). Granulomatous prostatitis associated with specific infections
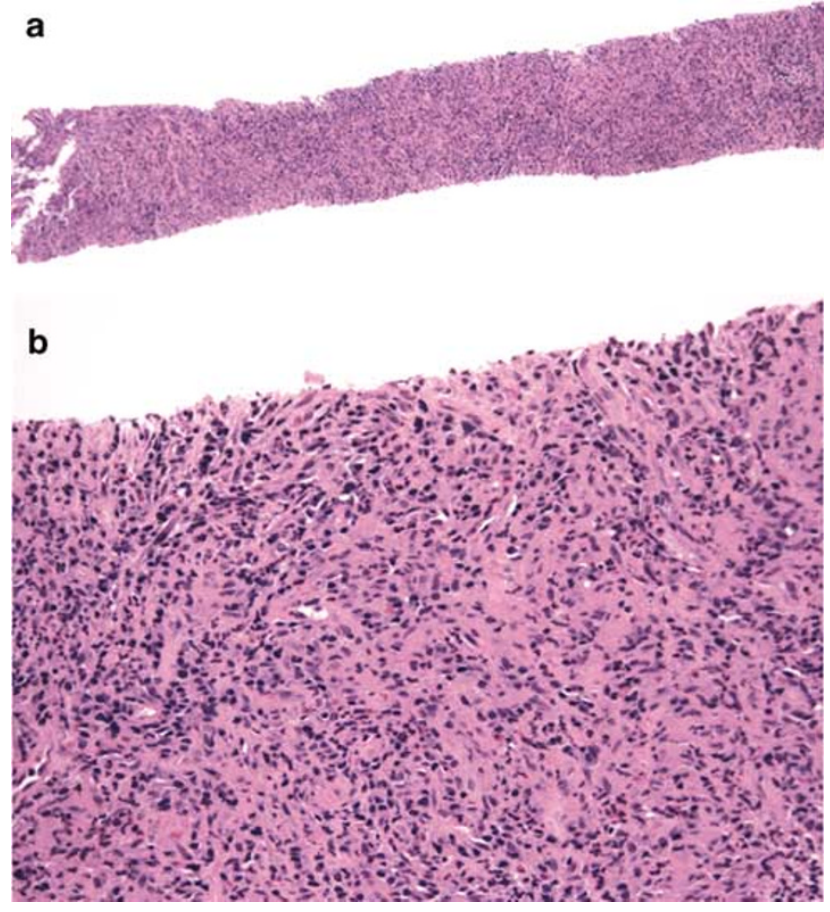

Figure 25 Nonspecific granulomatous prostatitis. (a) Low-power appearance in needle biopsy showing solid pattern. (b) Highpower appearance showing admixture of histiocytes and lymphocytes.

such as fungus and tuberculosis, BCG-associated granulomas and the procedural associated granulomas (palisading granulomas) do not usually cause problems in the differential diagnosis of adenocarcinoma.

\section{Degenerative changes in lymphocytes and stromal} cells

Lymphocytes and sometimes stromal cells may undergo degenerative changes which result in a signet ring-like morphology. ${ }^{114-116}$ If the change is prominent, the pattern can resemble high-grade adenocarcinoma composed of individual signet ring cells (Figure 27). The artifactual signet ring-like pattern, while initially described in transurethral resectates, may be found in needle biopsies. In the series of 47 cases, these 'atypical' cells were prominent in three cases and rare in 11 cases. ${ }^{115}$ It is very important to be aware of this phenomenon and not to overinterpret such cells as being malignant. In difficult cases, immunohistochemical stains can be used to confirm the nonepithelial nature of the cells.

\section{Summary}

There are a wide variety of patterns and processes that may be confused with one or more of the diverse patterns of prostatic adenocarcinoma. In general, recognition of this differential diagnosis coupled with careful routine microscopy will 

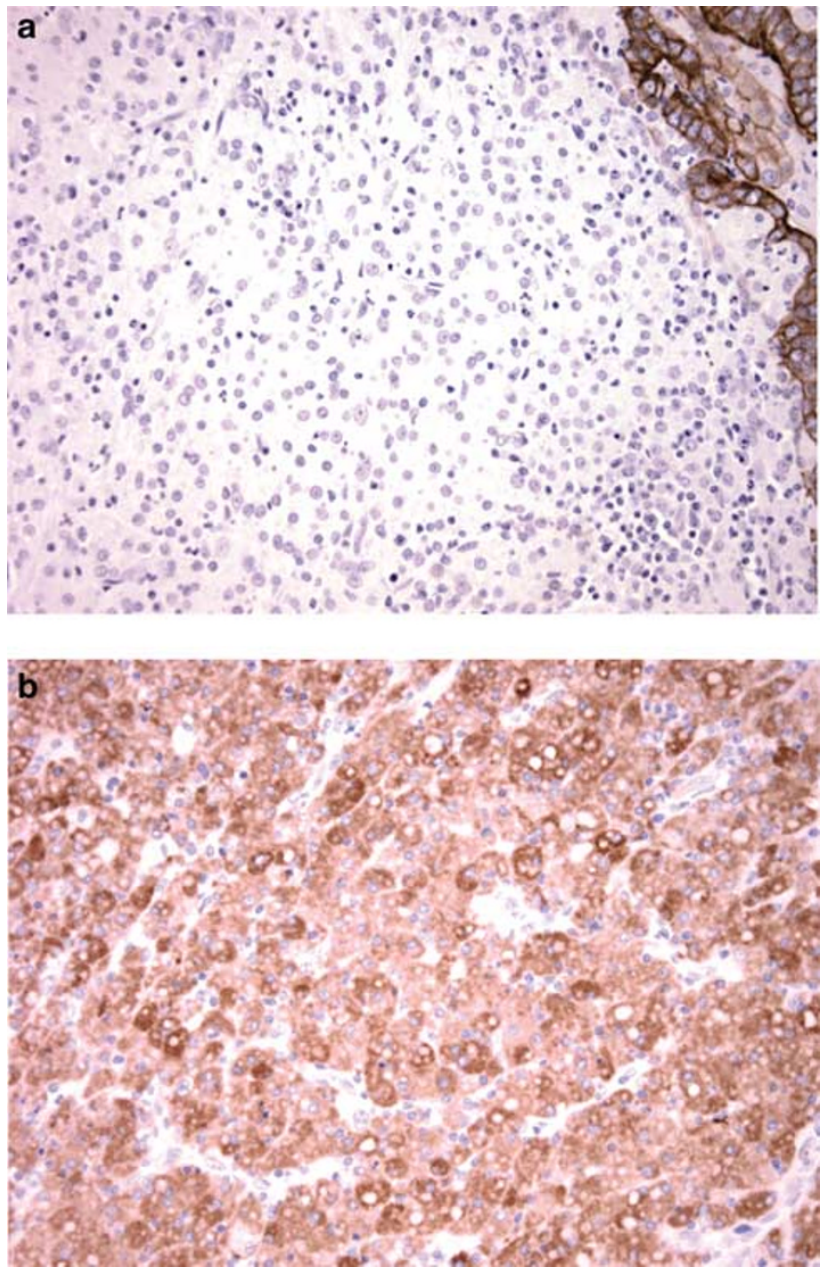

Figure 26 Granulomatous prostatitis (a) Immunohistochemistry for cytokeratin (CAM 5.2) -note positive glands (upper right) and negative staining of infiltrate. (b) Infiltrate stains positively for the macrophage marker, CD68.

lead to a correct diagnosis. In some instances however, ancillary immunohistochemical studies aimed at identifying prostatic basal cells (34 $\beta$ E12, CK5/6, p63), prostatic secretory cells (PSA, PAP, CD57), neuroendocrine cells (chromogranin, synaptophysin) and inflammatory cells (LCA, CD68) may be required to resolve a diagnostic dilemma (see Table 5). The new marker $\alpha$-methylacyl-CoA racemase (P504S) appears to be of value in supporting a diagnosis of adenocarcinoma, especially when one is dealing with small foci ${ }^{117,118}$ (Figure 28).

Awareness of the differential diagnosis of prostatic adenocarcinoma is especially important in the context of diagnosing limited carcinoma in small biopsy samples. It is important to always be aware of the potential of false-positive cancer diagnosis when looking at prostatic biopsies and to utilize appropriate consultation and ancillary studies to arrive at a confident and correct diagnosis.

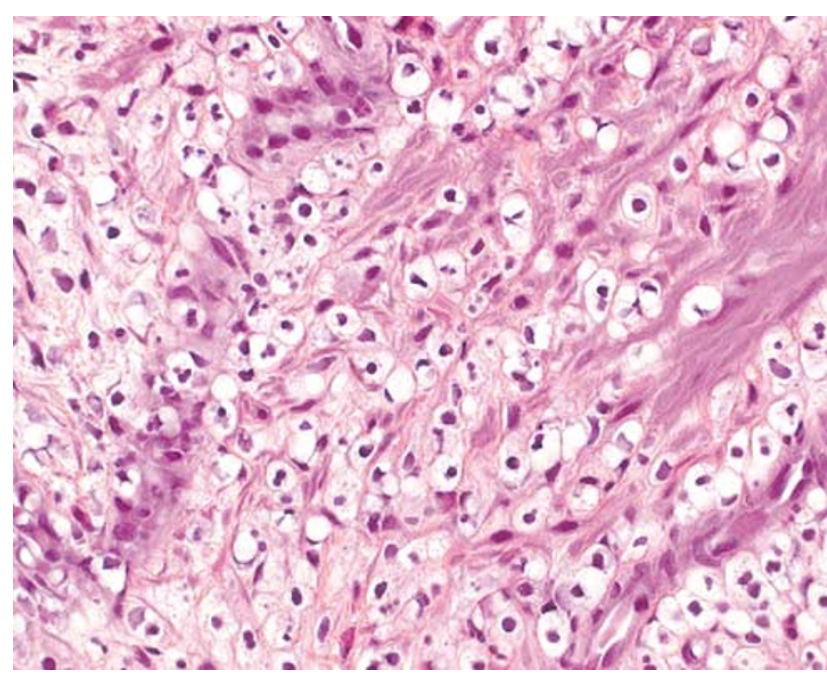

Figure 27 Degenerative changes in lymphocytes and stromal cells simulating signet ring pattern of prostatic adenocarcinoma.

Table 5 Benign mimickers of adenocarcinoma: useful immunohistochemical markers

Cytokeratins (general)

AE1/AE3, Cam 5.2, MAK6

Basal cell markers

34 $\beta \mathrm{E} 12$, CK5/6, p63

Secretory cell markers

Prostate-specific antigen (PSA), prostatic acid phosphatase (PAP), CD57

Neuroendocrine markers

Chromogranin, synaptophysin

Lymphohistiocytic markers

Leukocyte common antigen, CD56, CD68

Other markers

$\alpha$-Methylacyl-CoA racemase (P504S)

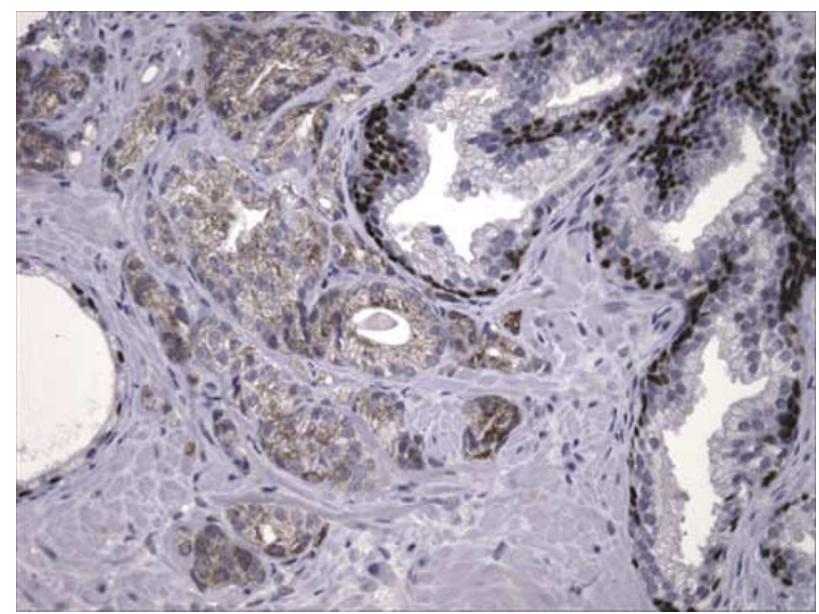

Figure 28 Small focus of adenocarcinoma stained with PIN cocktail (P504S + p63). Note non-neoplastic glands with prominent basal cells decorated with the nuclear stain, p63 (right). Centrally, there is an infiltrate of small glands lacking basal cells and staining positively for P504S. These markers are useful in the diagnosis and differential diagnosis of small foci of adenocarcinoma. 


\section{Acknowledgements}

We gratefully acknowledge the photographic assistance of David Charters and the excellent secretarial support provided by Barbara Jones.

\section{References}

1 Troxel DB, Sabella JD. Problem areas in pathology practice. Uncovered by a review of malpractice claims. Am J Surg Pathol 1994;18:821-831.

2 Troxel DB. Diagnostic pitfalls in surgical pathologydiscovered by a review of malpractice claims. Int J Surg Pathol 2001;9:133-136.

3 Fody EP, West Tan M. Steering clear of malpractice claims. CAP Today, November 2002;6:38-42.

4 Jones EC, Young RH. The differential diagnosis of prostatic carcinoma. Its distinction from premalignant and pseudocarcinomatous lesions of the prostate gland. Am J Clin Pathol 1994;101:48-64.

5 Bostwick DG, Dundore PA. Biopsy Pathology of the Prostate. Chapman and Hall: New York, 1997.

6 Gaudin PB, Reuter VE. Benign mimics of prostatic adenocarcinoma on needle biopsy. Anat Pathol 1997;2:111-134.

7 Helpap B. Differential diagnosis of glandular proliferations in the prostate. A conventional and immunohistochemical approach. Virchows Archiv 1998;433:397-405.

8 Srigley JR, Bullock M, Amin M. Small glandular patterns in the prostate gland: the differential diagnosis of small acinar carcinoma. In: Foster CS, Bostwick DG (eds). Pathology of the Prostate, Major Problems in Pathology Series, Vol. 34. WB Saunders Company: Philadelphia, 1998, pp. 126-156.

9 Young RH, Srigley JR, Amin MB, et al. Tumors of the prostate gland, seminal vesicles, male urethra and penis. Atlas of Tumor Pathology, 3rd Series, Fascicle 28, AFIP, 2000.

10 Epstein JI, Yang XJ. Prostate Biopsy Interpretation. Lippincott, Williams \& Wilkins: Philadelphia, 2002.

11 Gleason DF. Classification of prostatic carcinoma. Cancer Chemother Rep 1996;50:125-128.

12 Gleason DF. Histologic grading and clinical staging of prostatic carcinoma. In: Tannenbaum $\mathrm{M}$ (ed). Urologic Pathology: The Prostate. Lea \& Febiger: Philadelphia, 1977, pp. 171-197.

13 Kuo TT, Gomez LG. Monstrous epithelial cells in human epididymis and seminal vesicles. A pseudomalignant change. Am J Surg Pathol 1981;5: 483-490.

14 Jensen KM, Sonneland P, Madsen PO. Seminal vesicle tissue in 'resectate' of transurethral resection of prostate. Urology 1983;22:20-23.

15 Srigley JR. Small acinar patterns in the prostate gland with emphasis on atypical adenomatous hyperplasia and small acinar carcinoma. Semin Diagn Pathol 1988;5:254-272.

16 Arias-Stella J, Takano-Moron J. Atypical epithelial changes in the seminal vesicle. Arch Pathol 1958;66:761-766.

17 Brennick JB, O’Connell JX, Dickersin GR, et al. Lipofuscin pigmentation (so-called 'melanosis') of the prostate. Am J Surg Pathol 1994;18:446-454.
18 Leung CS, Srigley JR. Distribution of lipochrome pigment in the prostate gland: biological and diagnostic implications. Hum Pathol 1995;26:1302-1307.

19 Amin MB, Bostwick DG. Pigment in prostatic epithelium and adenocarcinoma: a potential source of diagnostic confusion with seminal vesicular epithelium. Mod Pathol 1996;9:791-795.

20 Cina SJ, Silberman MA, Kahane H, et al. Diagnosis of Cowper's glands on prostate needle biopsy. Am J Surg Pathol 1997;21:550-555.

21 Saboorian MH, Huffman H, Ashfaq R, et al. Distinguishing Cowper's glands from neoplastic and pseudoneoplastic lesions of prostate. Immunohistochemical and ultrastructural studies. Am J Surg Pathol 1997;21:1069-1074.

22 Grignon DJ, O’Malley FP. Mucinous metaplasia in the prostate gland. Am J Surg Pathol 1993;17:287-290.

23 Gardner. Jr WA, Culberson DE. Atrophy and proliferation in the young adult prostate. J Urol 1987;137: $53-56$.

24 Billis A. Prostatic atrophy: an autopsy study of a histologic mimic of adenocarcinoma. Mod Pathol 1998;11:47-54.

25 Bostwick DG, Egbert BM, Fajardo LF. Radiation injury of the normal and neoplastic prostate. Am J Surg Pathol 1982;6:541-551.

26 Sheaff MT, Baithun SI. Effects of radiation on the normal prostate gland. Histopathology 1997;30: 341-348.

27 Cheng L, Cheville JC, Bostwick DG. Diagnosis of prostate cancer in needle biopsies after radiation therapy. Am J Surg Pathol 1999;23:1173-1183.

28 Têtu B, Srigley JR, Boivin J, et al. Effect of combination endocrine therapy (LHRH agonist and flutamide) on normal prostate and prostatic adenocarcinoma. Am J Surg Pathol 1991;15:115-120.

29 Civantos F, Marcial MA, Banks ER, et al. Pathology of androgen deprivation in prostatic carcinoma. A comparative study of 173 patients. Cancer 1995;75: 1634-1641.

30 Bullock MJ, Srigley JR, Klotz LH, et al. Pathological effects of neoadjuvant cyproterone acetate on nonneoplastic prostate, prostatic intraepithelial neoplasia and adenocarcinoma: a detailed analysis of radical prostatectomy specimens from a randomized trial. Am J Surg Pathol 2002;26:1400-1413.

31 Hedrick L, Epstein JI. Use of keratin 903 as an adjunct in the diagnosis of prostate carcinoma. Am J Surg Pathol. 1989;13:389-396.

32 Epstein JI, Walsh PC, Sanfilippo F. Clinical and cost impact of second-opinion pathology. Review of prostate biopsies prior to radical prostatectomy. Am J Surg Pathol 1996;20:851-857.

33 Cina SJ, Epstein JI. Adenocarcinoma of the prostate with atrophic features. Am J Surg Pathol 1997;21: 289-295.

34 Kaleem Z, Swanson P, Vollmer RT, et al. Prostatic adenocarcinoma with atrophic features: a study of 202 consecutive completely embedded radical prostatectomy specimens. Am J Clin Pathol 1998;109: 695-703.

35 Franks LM. Atrophy and hyperplasia in the prostate proper. J Pathol Bact 1954;68:617-621.

36 Cheville JC, Bostwick DG. Post-atrophic hyperplasia of the prostate. A histologic mimic of prostatic adenocarcinoma. Am J Surg Pathol 1995;19: 1068-1076. 
37 Oppenheimer JR, Wills ML, Epstein JI. Partial atrophy in prostate needle cores: another diagnostic pitfall for the surgical pathologist. Am J Surg Pathol 1998;22: 440-445.

38 Amin MB, Tamboli P, Varma M, et al. Post-atrophic hyperplasia of the prostate gland: a detailed analysis of its morphology in needle biopsy specimens. Am J Surg Pathol 1999;8:925-931.

39 Liavag I. Atrophy and regeneration in the pathogenesis of prostatic carcinoma. Acta Pathol Microbiol Scand 1968;73:338-350.

40 De Marzo AM, Marchi VL, Epstein JI, et al. Proliferative inflammatory atrophy of the prostate. Implications for prostatic carcinogenesis. Am J Pathol 1999;155:1985-1992.

41 Putzi MJ, De Marzo AM. Morphologic transitions between proliferative inflammatory atrophy and highgrade prostatic intraepithelial neoplasia. Urol 2000;56:828-832.

42 Nelson WG, De Marzo AM, Deweese TL. The molecular pathogenesis of prostate cancer: implications for prostate cancer prevention. Urol 2001;57: 39-45.

43 Epstein J. Inflammatory atypia vs prostate adenocarcinoma with inflammation. In: Epstein J (ed). Differential Diagnosis in Pathology, Urologic Diseases. Igaku-Shoin: New York, 1992, pp 82-83.

44 Bennett BD, Richardson PH, Gardner WA. Histopathology and cytology of prostatitis. In: Lepor $\mathrm{H}$, Lawson R (eds). Prostate Diseases. WB Saunders: Philadelphia, 1993, pp 399-413.

45 Chan TY, Epstein JI. Follow up of atypical prostate needle biopsies suspicious for cancer. Urology 1999;53:351-355.

46 Young RH. Nephrogenic adenomas of the urethra involving the prostate gland: a report of two cases of a lesion that may be confused with prostatic adenocarcinoma. Mod Pathol 1992;5:617-620.

47 Daroca PJ, Martin AA, Reed RJ, et al. Nephrogenic adenoma of the prostatic urethra. A report of these cases including a case with infiltration of the prostatic stroma. J Urol Pathol 1993;1:157-172.

48 Malpica A, Ro JY, Troncoso P, et al. Nephrogenic adenoma of the prostatic urethra involving the prostate gland: a clinicopathologic and immunohistochemical study of eight cases. Hum Pathol 1994;25: 390-395.

49 Allan CH, Epstein JI. Nephrogenic adenoma of the prostatic urethra: a mimicker of prostate adenocarcinoma. Am J Surg Pathol 2001;25:802-808.

50 Mazal PR, Schaufler R, Altenhuber-Müller R, et al. Derivation of nephrogenic adenomas from renal tubular cells in kidney-transplant recipients. N Engl J Med 2002;347:653-659.

51 Cleary KR, Choi HY, Ayala AG. Basal cell hyperplasia of the prostate of the prostate. Am J Clin Pathol 1983;80:850-854.

52 Grignon DJ, Ro JY, Ordonez NG, et al. Basal cell hyperplasia, adenoid basal cell tumor, and adenoid cystic carcinoma of the prostate gland: an immunohistochemical study. Hum Pathol 1988;19: 1425-1433.

53 Devaraj LT, Bostwick DG. Atypical basal cell hyperplasia of the prostate. Immunophenotypic profile and proposed classification of basal cell proliferations. Am J Surg Pathol 1993;17: 645-659.
54 Van de Voorde W, Baldewijns M, Lauweryns J. Florid basal cell hyperplasia of the prostate. Histopathology 1994;24:341-348.

55 Thorson P, Swanson PE, Vollmer RT, Humphrey PA. Basal cell hyperplasia in the peripheral zone of the prostate. Mod Pathol 2003;16:598-606.

56 Epstein JI, Armas OA. Atypical basal cell hyperplasia of the prostate. Am J Surg Pathol 1992;16:1205-1214.

57 Humphrey PA, Kaleem Z, Swanson P, et al. Pseudohyperplastic prostatic adenocarcinoma. Am J Surg Pathol 1998;22:1239-1246.

58 Levi AW, Epstein JI. Pseudohyperplastic prostatic adenocarcinoma on needle biopsy and simple prostatectomy. Am J Surg Pathol 2000;24:1039-1046.

59 Young RH, Clement PB. Sclerosing adenosis of the prostate. Arch Pathol Lab Med 1987;111:363-366.

60 Chen KT, Schiff JJ. Adenomatoid prostatic tumor. Urology 1983;21:88-89.

61 Jones EC, Clement PB, Young RH. Sclerosing adenosis of the prostate gland. A clinicopathological and immunohistochemical study. Am J Surg Pathol 1991; 15:1171-1180.

62 Sakamoto N, Tsuneyoshi M, Enjoji M. Sclerosing adenosis of the prostate. Histopathologic and immunohistochemical analysis. Am J Surg Pathol 1991; 15:660-667.

63 Grignon DJ, Ro JY, Srigley JR, et al. Sclerosing adenosis of the prostate gland. A lesion showing myoepithelial differentiation. Am J Surg Pathol 1992; 16:383-391.

64 Gagucas RJ, Brown RW, Wheeler TM. Verumontanum mucosal gland hyperplasia. Am J Surg Pathol 1995;19:30-36.

65 Gaudin PB, Wheeler TM, Epstein JI. Verumontanum mucosal gland hyperplasia (VMGH) in prostatic needle biopsy specimens: a mimic of low-grade prostatic adenocarcinoma. Am J Clin Pathol 1995;104: 620-626.

66 Muezzinogou B, Erdamar S, Chakraborty S, et al. Verumontanum mucosal gland hyperplasia is associated with atypical adenomatous hyperplasia of the prostate. Arch Pathol Lab Med 2001;125:358-360.

67 Gikas PW, Del Buono EA, Epstein JI. Florid hyperplasia of mesonephric remnants involving prostate and periprostatic tissue. Possible confusion with adenocarcinoma. Am J Surg Pathol 1993;17: 454-460.

68 Amin MB. Florid hyperplasia of mesonephric remnants: yet another differential diagnostic consideration under 'small acinar proliferations of the prostate'. Adv Anat Pathol 1995;2:108-113.

69 Val-Bernal JF, Gomez-Ortega JM. Hyperplasia of prostatic mesonephric remnants: a potential pitfall in the evaluation of prostate gland biopsy. J Urol 1995;154:1138-1139.

70 Muir TE, Pacelli A, Farrow GM, et al. Mesonephric remnants of the prostate: incidence and clinical significance [Abstract]. Mod Pathol 1997;10:83A.

71 Jimenez RE, Raval MF, Spanta R, et al. Mesonephric remnants hyperplasia. Pitfall in the diagnosis of prostatic adenocarcinoma. J Urol Pathol 1998;9: 83-92.

72 McNeal JE. Morphogenesis of prostatic carcinoma. Cancer 1965;18:1659-1666.

73 Gleason DF. Atypical hyperplasia, benign hyperplasia, and well-differentiated adenocarcinoma of the prostate. Am J Surg Pathol 1985;9(Suppl):a53-a67. 
74 Bostwick DG, Srigley J, Grignon D, et al. Atypical adenomatous hyperplasia of the prostate: morphologic criteria for its distinction from welldifferentiated carcinoma. Hum Pathol 1993;24: 819-832.

75 Amin MB, Ro JY, Ayala AG. Putative precursor lesions of prostatic adenocarcinoma: fact or fiction? Mod Pathol 1993;6:476-483.

76 Bostwick DG, Qian J. Atypical adenomatous hyperplasia of the prostate. Relationship with carcinoma in 217 whole-mount radical prostatectomies. Am J Surg Pathol 1995;19:506-518.

77 Grignon DJ, Sakr WA. Atypical adenomatous hyperplasia of the prostate: a critical review. Eur Urol 1996; 30:2206-2211.

78 Cheng L, Shan A, Cheville JC, et al. Atypical adenomatous hyperplasia of the prostate: a premalignant lesion? Cancer Res 1998;58:389-391.

79 Bostwick DG, Algaba F, Amin MB, et al. Consensus statement on terminology: recommendation to use atypical adenomatous hyperplasia in place of adenosis of the prostate [Letter]. Am J Surg Pathol 1994;18:1069-1070.

80 Epstein JI. Adenosis vs. atypical adenomatous hyperplasia of the prostate [Letter]. Am J Surg Pathol 1994;18:1070-1071.

81 Gaudin PB, Epstein JI. Adenosis of the prostate. Histologic features in transurethral resections specimens. Am J Surg Pathol 1994;18:863-870.

82 Gaudin PB, Epstein JI. Adenosis of the prostate. Histologic features in needle biopsy specimens. Am J Surg Pathol 1995;19:737-747.

83 Epstein JI. Adenosis (atypical adenomatous hyperplasia): histopathology and relationship to carcinoma. Path Res Pract 1995;191:888-898.

84 Brawn PN. Adenosis of the prostate: a dysplastic lesion that can be confused with prostate adenocarcinoma. Cancer 1982;49:826-833.

85 O’Malley FP, Grignon DJ, Shum DT. Usefulness of immunoperoxidase staining with high-molecular weight cytokeratin in the differential diagnosis of small acinar lesions of the prostate gland. Virchows Arch [A] 1990;417:191-196.

86 Helpap B. The biological significance of atypical hyperplasia of the prostate. Virchows Arch [A] 1980;387:307-317.

87 Helpap B. Cell kinetic studies on prostatic intraepithelial neoplasia (PIN) and atypical adenomatous hyperplasia (AAH) of the prostate. Pathol Res Pract 1995;191:904-907.

88 Ghazizadah M, Sasaki Y, Oguro T, et al. Silver staining of nucleolar organizer regions in prostate lesions. Histopathology 1991;19:369-372.

89 Doll JA, Zhu X, Furman J, et al. Genetic analysis of prostatic atypical adenomatous hyperplasia (adenosis). Am J Pathol 1999;155:967-971.

90 Yang XJ, Wu CL, Woda BA, et al. Expression of $\alpha$-methylacyl-CoA racemase (P504S) in atypical adenomatous hyperplasia of the prostate. Am J Surg Pathol 2002;26:921-925.

91 Epstein JI, Fynheer J. Acidic mucin in the prostate: can it differentiate adenosis from adenocarcinoma? Hum Pathol 1992;23:1321-1325.

92 Goldstein NS, Qian J, Bostwick DG. Mucin expression in atypical adenomatous hyperplasia of the prostate. Hum Pathol 1995;26:887-891.
93 Ayala AG, Srigley JR, Ro JY, et al. Clear cell cribriform hyperplasia of prostate. Report of 10 cases. Am J Surg Pathol 1986;10:665-671.

94 Frauenhoffer EE, Ro JY, El-Naggar AK, et al. Clear cell cribriform hyperplasia of the prostate. Immunohistochemical and DNA flow cytometric study. Am J Clin Pathol 1991;95:446-453.

95 Reed RJ. Consultation case: prostate (prostatectomy)_adenoid basal cell tumor-multifocal basal cell hyperplasia. Am J Surg Pathol 1984;8: 699-704.

96 Young RH, Frierson HF, Mills SE, et al. Adenoid cystic-like tumor of the prostate gland. A report of two cases and review of the literature on 'adenoid cystic carcinoma' of the prostate. Am J Clin Pathol 1988;89:49-56.

97 Freedman SR, Goldman RL. Normal paraganglia in the human prostate. J Urol 1975;113:874-875.

98 Rode J, Bentley A, Parkinson C. Paraganglial cells of urinary bladder and prostate: potential diagnostic problem. J Clin Pathol 1990;43:13-16.

99 Ostrowski ML, Wheeler TM. Paraganglia of the prostate. Location, frequency, and differentiation from prostatic adenocarcinoma. Am J Surg Pathol 1994;18:412-420.

100 Sebo TJ, Bostwick DG, Farrow GM, et al. Prostatic xanthoma: a mimic of prostate adenocarcinoma. Hum Pathol 1994;25:386-389.

101 Bostwick DG, Chang L. Overdiagnosis of prostatic adenocarcinoma. Sem Urol Oncol 1999;17:199-205.

102 McClure J. Malakoplakia of the prostate: a report of two cases and a review of the literature. J Clin Pathol 1979;32:629-632.

103 Koga S, Arakaki Y, Matsuoka M, et al. Malakoplakia of prostate. Urology 1986;27:160-161.

104 Thrasher JB, Sutherland RS, Limoge JP, et al. Transrectal ultrasound and biopsy in diagnosis of malakoplakia of prostate. Urology 1992;39:262-265.

105 Liu S, Christmas TJ, Kirby RS. Malakoplakia and carcinoma of the prostate. Br J Urol 1993;72: 120-121.

106 Sarma HN, Ramesh K, al Fituri O, et al. Malakoplakia of the prostate gland-report of two cases and review of the literature. Scand J Urol Nephrol 1996;30: 155-157.

107 Lopez-Plaza I, Bostwick DG. Prostatitis. In: Bostwick DG (ed). Pathology of Prostate. Churchill Livingstone: New York, 1990, pp. 15-30.

108 Bennett BD, Richardson PH, Gardner WA. Histopathology and cytology of prostatitis. In: Lepor $\mathrm{H}$, Lawson R (eds). Prostate Diseases. WB Saunders: Philadelphia, 1993, pp. 399-413.

109 Helpap B. Histological and immunohistochemical study of chronic prostatic inflammation with and without benign prostatic hyperplasia. J Urol Pathol 1994;2:49-64.

110 Kelalis PP, Greene LF, Harrison EG. Granulomatous prostatitis. A mimic of carcinoma of the prostate. JAMA 1965;191:287-289.

111 Taylor EW, Wheelis RF, Correa RJ, et al. Granulomatous prostatitis: confusion clinically with carcinoma of the prostate. J Urol 1977;117:3168.

112 Presti B, Weidner N. Granulomatous prostatitis and poorly differentiated prostate carcinoma. Their distinction with the use of immunohistochemical methods. Am J Clin Pathol 1991;95:330-334. 
113 Oppenheimer JR, Kahane H, Epstein JI. Granulomatous prostatitis on needle biopsy. Arch Pathol Lab Med 1997;121:724-729.

114 Alguacil-Garcia A. Artifactual changes mimicking signet ring cell carcinoma in transurethral prostatectomy specimens. Am J Surg Pathol 1986;10:795-800.

115 Schned AR. Artifactual signet ring cells. Am J Surg Pathol 1987;11:736-737.

116 Wang HL, Humphrey PA. Exaggerated signet-ring cell change in stromal nodule of prostate. A pseudoneo- plastic proliferation. Am J Surg Pathol 2002;26: 1066-1070.

117 Jiang Z, Woda BA, Rock KL, et al. P504S. A new molecular marker for the detection of prostate cancer. Am J Surg Pathol 2001;25:1397-1404.

118 Jiang Z, Wu CL, Woda BA, et al. P504S/ $\alpha$-methylacyl-CoA racemase. A useful marker for diagnosis of small foci of prostatic carcinoma on needle biopsy. Am J Surg Pathol 2002;26:1169-1174. 